\title{
Employee Representation and Financial Leverage $e^{\text {ts }}$
}

\author{
Chen $\operatorname{Lin}^{\mathrm{a}}$, Thomas Schmid ${ }^{\mathrm{b}}$, Yuhai Xuan ${ }^{\mathrm{c}, *}$ \\ ${ }^{a}$ Faculty of Business and Economics, University of Hong Kong (chenlin1@hku.hk) \\ ${ }^{b}$ Faculty of Business and Economics, University of Hong Kong (schmid@hku.hk) \\ ${ }^{c}$ Department of Finance, University of Illinois at Urbana-Champaign (yhxuan@illinois.edu)
}

\begin{abstract}
We analyze how direct employee voice affects financial leverage. German law mandates that firms' supervisory boards consist of an equal number of employees' and owners' representatives. This requirement, however, applies only to firms with over 2,000 domestic employees. We exploit this discontinuity and the law's introduction in 1976 for identification and find that direct employee power increases financial leverage. This is explained by a supply side effect: as banks' interests are similar to those of employees, higher employee power reduces agency conflicts with debt providers, leading to better financing conditions. These findings reveal a novel mechanism of direct employee influence.
\end{abstract}

Keywords: Capital structure, financial leverage, employee representation, labor rights, bank ownership

JEL: G32, J50

\footnotetext{
${ }^{\star}$ We thank an anonymous referee, Jonathan Berk, Tarun Chordia, Craig Doige, Jarrad Harford, Harald Hau, Florian Heider, Macin Kacperczyk, Christoph Kaserer, Ross Levine, Kai Li, Ernst Maug, Paige Ouimet, Daniel Paravisini, Luigi Pistaferri, Bill Schwert (the editor), Alex Stomper, Sheridan Titman, Neng Wang, Jianfeng Yu, and participants of the 2015 WFA Annual Meeting in Seattle, the 2015 EFA Annual Meeting in Vienna, and the 2015 CSEF-EIEF-SITE Conference on Finance and Labor in Rome for helpful comments.

${ }^{*}$ Corresponding author.
} 


\section{Introduction}

In this paper, we analyze how direct labor influence affects financial leverage. Direct forms of employee influence, such as informal speak-up programs, works councils, and employees on boards, are increasingly outranking traditional ways of labor representation. ${ }^{1}$ This transition from indirect labor influence (e.g., via unions) to a more direct employee voice sharpens the discussion on employees' role in corporate governance and presents novel challenges to firms and policy makers alike. However, in contrast to indirect influence of labor, surprisingly little is known about the consequences of a direct employee voice for corporate decision making.

We exploit a unique setting that grants employees a direct voice in the firm: the German law on codetermination. This law was introduced in 1976 and mandates that the supervisory board of a firm, which is similar to the board of directors, has to consist of an equal number of owners' and employees' representatives. We refer to this as parity employee representation $(\mathrm{PER}){ }^{2}$ For the empirical estimation of the consequences of direct employee influence, this setting has two desirable features. First, the granted influence is substantial. As employees tend to vote together, they can even outvote owners if they are divided by disagreement. Second, we can apply two independent identification strategies based on the law's introduction and design because it only applies to firms with more than 2,000 domestic employees. Using the discontinuity around this mandated threshold as well as the law's introduction in a difference-in-differences setting allows us to identify the causal impact of direct

\footnotetext{
${ }^{1}$ For instance, Wilkinson et al. (2014) state that "[i]n recent years, diminishing union density in advanced economies has shifted the form of voice in most organizations and countries from collective and unionized channels of representation to direct and individualized mechanisms" (p. 3).

${ }^{2}$ An alternative term for parity employee representation is parity codetermination. We use both terms interchangeably in this paper. Codetermination in this paper refers to board-level codetermination, whereas another form of employee voice, i.e., the "Betriebsrat"(or works council) is also often referred to as codetermination (at the establishment or plant level). Such works councils can be established in firms with more than five employees and give workers a voice, mainly with regard to employment conditions such as workplace safety or vacation policies (cf. Freeman, 1991; Freeman and Rogers, 1993; Freeman and Lazear, 1995, for details about works councils). In our sample, virtually all firms have works councils because we focus on medium-sized and large firms. Thus, our findings can be interpreted as the effect of board-level codetermination on top of codetermination by works councils.
} 
employee power.

Despite its importance in practice, the empirical literature on direct labor influence is still scarce. Faleye, Mehrotra and Morck (2006) and Kim and Ouimet (2014), for instance, investigate ownership by employees, but neither analyzes the impact on financing decisions. ${ }^{3}$ The literature on labor and financial leverage focuses on an indirect influence of employees, either via labor unions (e.g., Bronars and Deere, 1991) or legal protection (e.g., Ellul and Pagano, 2015). However, direct influence via a voice in firms' governance structure is likely very different from influence via such indirect channels. Due to their presence on corporate boards, employee representatives are well informed and able to exert direct pressure on executive managers.

We hypothesize that their direct voice reduces agency conflicts between banks and firms. Although employee representatives aim to protect the interests of employees in the first place, they may unintentionally also represent the interests of banks. The reason for this is that both employees and debt providers are risk-averse and have a strong interest in the long-term survival and stability of the firm. If this hypothesis holds true, we expect firms with PER to have lower firm risk, more favorable financing conditions, and - as a consequence - higher financial leverage, compared to firms without PER.

We start by analyzing the impact of PER on financial leverage based on a regression discontinuity design (RDD) around the threshold of 2,000 domestic employees. In particular, we compare firms that are slightly above the threshold with those slightly below. We assume that these firms are similar in all dimensions except their level of employee representation. As an alternative identification approach, we use a difference-in-differences (DiD) setting around the law's introduction in 1976. Thereby we compare treated firms, i.e., those firms which had to introduce PER due to the new law to unaffected control firms. We find consistent evidence across both

\footnotetext{
${ }^{3}$ Employee stock ownership also grants employees a direct influence in the decision process via their votes. However, although employee ownership is on the rise, labor's influence via this channel is mostly still limited due to low equity stakes, and ownership is likely endogenously determined, making identification challenging.
} 
different estimation techniques which shows that financial leverage is about $5 \%$ to $10 \%$ higher in firms with PER compared to firms without strong employee power.

For the RDD analysis, the identification assumption is that firms cannot precisely manipulate the number of domestic employees in the interval near the cut-off. Although manipulation may be theoretically possible, our evidence does not indicate that the threshold is actually manipulated in practice (cf. Atanasov and Black, 2016, p. 97). First, owners and managers are well aware that they cannot avoid codetermination in the long run if they want the firm to grow. Thus, the real option value of delaying growth is small. Second, the law exists since 1976, with only minor changes since then. If there would be evidence for large-scale manipulation, the legislator would have adjusted the law. Third, the McCrary (2008) test shows that the distribution of domestic employees is smooth around the threshold. Fourth, we repeat the analysis for high-growth industries in which a precise manipulation of the threshold is more difficult and find similar results. We also show that the covariates are continuous around the threshold. Overall, these tests cannot completely rule out the possibility of manipulation, but they help to mitigate concerns that this drives our findings.

To further challenge the validity of our RD strategy, we follow the suggestions in Angrist and Pischke (2008) and alternatively apply very narrow windows around the threshold. Using bandwidths of up to 1,900 to 2,100 domestic employees, we find that the coefficient remains stable. We also apply a non-parametric, local RD estimator and find very similar results, both in terms of magnitude and statistical significance. Despite the fact that we already control for the number of domestic employees in all models, we also conduct placebo tests with randomly chosen thresholds and match PER and non-PER firms by size (i.e., total assets) to further mitigate concerns that size differences bias our findings.

Overall, these findings provide evidence for the validity of our RD approach. However, as mentioned before it is difficult to completely rule out all manipulation concerns in this setting. Thus, we also present evidence based on a second setting 
in which we exploit the introduction of the law on codetermination in 1976. In this setting, manipulation may still be possible, but it is less likely a major concern because i) the threshold of 2,000 was not largely known before the law's announcement and ii) adjusting firm size, especially downwards, takes time. Thus, it was difficult for firms to precisely manipulate their number of domestic employees to avoid PER. Even if they wanted, many firms very likely could not strategically shrink below the threshold when the law was introduced because they could not adjust their number of domestic employees downwards fast enough. In the difference-in-differences estimation we compare changes in leverage of these "treated" firms with that of other firms that were unaffected by the law. We also show that treated and control firms have a similar development of financial leverage before the law was enacted ("parallel trends assumption") and that differences in firms' size are unlikely to drive our findings.

We hypothesize that reduced agency conflicts between banks and firms with parity codetermination drive our results. However, an alternative explanation for higher leverage in PER firms could be related to bargaining power. To investigate whether our findings are indeed due to an interest alignment effect, we perform several additional tests. First, we focus on a possible substitute for PER which also allows banks to directly enforce their interests: bank ownership. We find that the PER effect does not exist for firms which have banks as owners based on the RDD analysis. Furthermore, the impact of changes in the codetermination status over time on financial leverage is close to zero for firms with bank ownership. To mitigate concerns that these findings are biased by endogenously determined bank ownership, we also exploit the capital gains tax reform in 2000 as an exogenous shock which led to a reduction of equity holdings by German banks. Analyzing firms with bank ownership before the tax reform in a difference-in-differences setting reveals that only those without PER reduced their financial leverage in the post-event period. For PER firms, we find no effect. Overall, these three test settings provide strong evidence for a substitution effect between bank ownership and employee codetermination. 
Second, we analyze the cost of debt and find - in line with the view that employee power reduces agency conflicts between firms and banks - that firms with higher employee power have significantly lower loan spreads. Furthermore, these firms have longer debt maturities and fewer covenants.

A possible channel for this interest alignment effect is lower firm risk. To shed light on this possible channel, we start by analyzing firms' investment decisions, i.e., their M\&A deals and capital expenditures. In line with our expectations, we find that, compared to firms without PER, codetermined firms are less likely to conduct M\&A deals. Furthermore, they tend to focus on value-increasing deals if they engage in M\&A activities. Moreover, we demonstrate that cash flows and profits of these firms are less volatile. Lastly, firms with PER also have lower idiosyncratic risk. Thus, higher stability of codetermined firms provides a possible explanation for their interest alignment with debt providers.

Although this paper is, to the best of our knowledge, the first study to focus on the effects of parity codetermination on financial leverage, others have also analyzed the consequences of German codetermination. This literature goes back at least to Jensen and Meckling (1979), which analyzes the problems surrounding the role of labor in the firm for a variety of structures including codetermination in which management participation by labor is required by law. Jensen and Meckling (1979) argue that labor may have objective functions and incentives that are different from valuemaximizing shareholders and discuss the implications of labor voice for valuation, productivity, and governance, which frames the whole subject for much subsequent research. The majority of the existing studies on German codetermination focus on performance and valuation implications (e.g., Baums and Frick, 1998; Gorton and Schmid, 2004; Fauver and Fuerst, 2006) or productivity (e.g., Svejnar, 1981, 1982; FitzRoy and Kraft, 1993). The prior work most related to our study is Benelli, Loderer and Lys (1987), which investigates how codetermination affects corporate operations and performance using an event study framework. Although not their focus, the authors also look at the effect of codetermination on risk-taking. These 
results, while directionally in line with our finding, are "very weak and rarely statistically significant" (Benelli, Loderer and Lys, 1987). In contrast, the use of the regression discontinuity methodology in our study allows us to use data from more than just the period around the law's introduction, significantly increasing our sample size. Our empirical findings provide clean, strong evidence for a significant effect of PER on financial leverage and firm risk. Moreover, we go a step further and shed light on the channels through which PER affects leverage. By analyzing the role of banks, debt characteristics, and M\&A activities, we are able to identify the interest alignment effect, a novel channel that connects labor interests to bank interests.

The remainder of this paper is structured as follows. Section 2 summarizes the labor regulation context in Germany as well as theoretical considerations and our empirical strategy. The dataset is presented in Section 3. In Section 4, we show the results for the relationship between PER and financial leverage. We also investigate the necessary assumptions for the identification strategy and the general robustness of the results. We shed light on interest alignment between banks and firms with PER in Section 5 and possible channels for such alignment in Section 6. Finally, Section 7 concludes by summarizing the findings and their implications.

\section{Setting}

\subsection{Parity employee representation in Germany}

The regulation of labor differs across countries (e.g., Botero et al., 2004). In this paper, we focus on Germany as a country with a rather stringent labor regulation. In general, public companies in this country have a two-tier board system with a management board and a supervisory board ("Vorstand" and "Aufsichtsrat"). The former consists of executive managers who are responsible for the daily business. The members of the supervisory board have, among others, the duty to supervise the executive managers $(\S 111,1$ AktG). Furthermore, they elect the members of the management board for at most five years, with the possibility of re-election $(\S 84$, 1). Although the supervisory board has formally no influence on daily firm policy, 
this provides them with an effective mean to influence managers' decision making: if they are not satisfied, they can deny managers' re-election. Overall, the supervisory board has a similar role as the board of directors.

Employee representation on corporate boards of German firms is regulated by the law on codetermination ("Mitbestimmungsgesetz", MitBestG). The roots of this law go back to at least the post-World War II years. In 1951, the "MontanMitbestimmungsgesetz" granted employees in the iron and steel industry a voice in their firms' governance structure. In 1976, the law on codetermination came into force and extended employee representation to all industries (a more detailed description of the history of the law and it's introduction is presented in Section 2.3.2). Since then, there have been no fundamental changes or major reforms of the basic aspects of this law.

This law mandates that $50 \%$ of a firm's supervisory board seats belong to employee representatives, who are elected by the firm's employees. However, it applies only to firms (both public and private) with more than 2,000 domestic employees $(\S 1) .{ }^{4}$ For the calculation of the number of domestic employees, all firms within one group of companies, i.e., those of the parent company and all subsidiaries are considered (§5). For firms which exceed this threshold, the law mandates that the supervisory board has to consist of an equal number of owners' and employees' representatives $(\S 7) .{ }^{5}$ We refer to this equality as parity employee representation (PER) or parity employee codetermination in this paper. ${ }^{6}$

\footnotetext{
${ }^{4}$ To the best of our knowledge, no other legally mandated change happens at the threshold of 2,000 domestic employees. Some firms are exempt from the law $(\S 1,4)$. In our dataset, this is only relevant for firms which focus on news reporting, e.g., publishing companies, which we drop from the sample (see Section 3.1).

${ }^{5}$ The chairman of the board is elected by the owners' representatives, whereas the employee representatives elect the vice-chairman $(\S 27)$. As the chairman has two votes in case of a tie, owners have slightly more power than employees (§29). However, in reality this is often not the case because employee representative tend to vote en bloc, whereas different owners often have heterogeneous voting behavior.

${ }^{6}$ Companies with up to 2,000 , but more than 500 domestic employees are regulated by the onethird codetermination law ("Drittelbeteiligungsgestz", DrittelbG). This law states that one-third of the supervisory board has to consist of employee representatives. However, the power of this law is much weaker if compared to the MitBestG due to several reasons: (i) one-third codetermination can more easily be ignored by owners' representatives than parity codetermination, (ii) the law does not apply to some legal forms (e.g., to the GmbH \& Co KG), (iii) employees of other firms in the
} 
Several studies analyze performance consequences of codetermination in Germany. Theoretically, PER can increase performance, e.g., due to higher commitment of employees or because employee representatives posses superior information about employees and improve resource allocation within the firm (Berk, Van Binsbergen and Liu, 2014). On the contrary, codetermination can also be detrimental to performance, e.g., because of rent-seeking behavior of employees. For instance, Kim, Maug and Schneider (2015) show that codetermination protects skilled workers against layoffs during industry shocks. The empirical evidence on codetermination and profitability is mixed and inconclusive (e.g., Fauver and Fuerst, 2006). ${ }^{7}$

\subsection{Theoretical considerations and related literature}

Our empirical setting is different from most of the prior literature along two dimensions. First, the majority of the literature focuses on an indirect influence of labor on firm policy, e.g., via industry-level unionization. By contrast, we investigate a direct influence of employees on corporate decision due to their representation on the firm's supervisory board. Second, we study a setting with a legally mandated shift of power. In particular, the increase in employee power goes along with a reduction of owners' power as supervisory board seats are reallocated from owners to employees in firms with PER.

Prior literature on the relationship between financial leverage and employee power mainly focuses on two perspectives: bargaining and employment protection. The bargaining literature argues that firms use debt as a strategic bargaining tool. In this perspective, firms increase leverage, for instance, before wage negotiations with employees to improve their bargaining position. Theoretical and empirical evi-

group of companies are not necessarily considered ( $\S 2,2$ DrittelbG). The last two aspects allow firms to strategically avoid one-third codetermination. These possibilities do not exist for parity codetermination (Rieble, 2006).

${ }^{7}$ Valuation and performance consequences of labor power have also been studied outside Germany. For example, Faleye, Mehrotra and Morck (2006) investigate various dimensions and find, among others, that labor-controlled firms have lower firm value. Ginglinger, Megginson and Waxin (2011), however, find that employee directors increase firm valuation and corporate performance. Another strand of the literature focuses more generally on the relationship between labor regulation and economic outcomes (e.g., Botero et al., 2004) or the relationship between workers and managers (e.g., Pagano and Volpin, 2005; Atanassov and Kim, 2009). 
dence for this view is, among others, provided by Bronars and Deere (1991), Perotti and Spier (1993), or Matsa (2010). Ellul and Pagano (2015) extend this view by incorporating the seniority of employees' claims in default and their rights during debt renegotiation. According to the bargaining argument, higher employee power due to PER is generally expected to lead to higher financial leverage as managers may try to increase their bargaining power over employee representatives by reducing firms' financial slack. ${ }^{8}$

The second perspective is related to employment protection. The main idea is that higher financial leverage reduces employees' job safety. Consequently, employees prefer lower levels of debt to reduce the probability of financial distress. Berk, Stanton and Zechner (2010) show in their theoretical model that bankruptcy costs borne by employees play a significant role in counterbalancing the tax benefits of debt. Empirical support that the human costs of bankruptcy are economically highly important is provided by Graham et al. (2015). Several consequences emerge from this perspective. First, firms' institutional environments, e.g., the level of labor protection or unemployment benefits, may affect their debt-equity choice. Simintzi, Vig and Volpin (2015), for instance, study reforms increasing employment protection and find that their impact on leverage is negative. Second, firms with higher levels of debt may attract less (qualified) employees and pay higher wages to compensate workers for higher probability of financial distress (Chemmanur, Cheng and Zhang, 2013). Thus, firms may want to maintain lower levels of debt in order to be more employee friendly (Bae, Kang and Wang, 2011). Additionally, employees with high power may try to increase their job safety and demand insurance against adverse

\footnotetext{
${ }^{8}$ Due to the direct influence of employees, the use of debt as a strategic bargaining tool may be less likely in our setting. There are three reasons for this. First, employee representatives on the supervisory board have the duty to monitor executive managers ( $\$ 111,1$ AktG). If debt levels are high and employees are concerned about their jobs, their representatives are more likely to monitor executive managers tightly. Thus, executive managers have incentives to choose conservative debt levels to escape tight monitoring. Second, employee representatives can threaten executive managers with not re-electing them if they disagree with the firm's financial policy $(\S 84,1)$. Third, the representatives of the employees possess insider knowledge about the firm's need for debt because they have the right to inspect the firm's internal documents $(\S 111,2)$. Thus, it is difficult for managers or owners to push debt levels excessively high in order to improve their bargaining position.
} 
firm shocks (Guiso, Pistaferri and Schivardi, 2005; Ellul, Pagano and Schivardi, 2015; Kim, Maug and Schneider, 2015). According to this perspective, higher employee power may also enable them to "force" firms to reduce risk by choosing lower levels of financial leverage. Thus, the employment protection perspective predicts that firms with PER should have lower levels of financial leverage.

In this paper we also consider a third perspective that may be highly relevant in a setting where employees have a direct voice in a firm's governance system: interest alignment between firms with parity employee representation and banks. Besides the general monitoring of the board (Schwartz-Ziv and Weisbach, 2013), employee representatives may unintentionally engage in cross-monitoring for banks as both stakeholders are risk-averse and mainly interested in the survival of the firm. Monitoring is a core task of banks (e.g., Campbell and Kracaw, 1980). However, monitoring is also costly, and firms with too high monitoring cost may face problems to obtain credits (e.g., Williamson, 1987). Nevertheless, banks are generally assumed to have a cost advantage of monitoring compared to public debt holders, e.g., because they have (limited) access to inside information. Such cross-monitoring by banks may diminish "duplicative monitoring and bonding costs of other debtholders" (Datta, Iskandar-Datta and Patel, 1999, p. 436) and reduce firms' bond yields. ${ }^{9}$

A similar cross-monitoring effect may also occur with employee representatives. Unlike banks engaging in monitoring for public debt holders, banks now profit from monitoring activities by employee representatives as they unintentionally take over part of the monitoring for banks, which reduces banks' monitoring cost. As manages have no influence on the appointment of employee representatives, their monitoring may be especially valuable (Hermalin and Weisbach, 1998). The reason why the employee representatives unintentionally take over part of the monitoring by banks is that their preferences are similar. In contrast to equity holders, both banks and workers are often regarded as being risk-averse stakeholders (e.g., Ratti, 1980; Gor-

\footnotetext{
${ }^{9}$ Furthermore, firms can use their transactions with banks to build a good reputation before entering public debt markets (Diamond, 1991).
} 
ton and Schmid, 2000; Berk, Stanton and Zechner, 2010) who have fixed claims: workers receive their wages and other contractual benefits like pensions, and banks receive interest and debt repayment as long as the firm is not in default. Thus, both have large incentives to influence firm policy in a way that reduces firm risk and the probability of insolvency. ${ }^{10}$ In particular, equity holders may prefer high-risk investment projects (e.g., Jensen and Meckling, 1976). However, neither employees nor banks directly profit from these risky investment projects, but both suffer from reduced job safety and increased probability that debt repayments fail. Thus, both stakeholders prefer less risky investments. ${ }^{11}$ Empirical evidence for lower risk taking of employee-controlled firms is, for instance, provided by Faleye, Mehrotra and Morck (2006). Furthermore, employee representatives may help to prevent managerial myopia and an excessive focus on short-term gains (e.g., Stein, 1989), also beneficial to banks which are more interested in the long-term survival of the firm than in short-term optimization. Cross-monitoring by employee representatives may be especially valuable due to their direct voice and high level of insider knowledge which enable them to effectively enforce their and the banks' interests; in fact, their possibilities to affect firm policy (e.g., by threatening managers to deny re-election) are much higher than for banks.

Consequently, we expect an interest alignment between firms with PER and banks. This leads to several testable predictions: first, we expect firms with PER to have lower firm risk, i.e., to engage less in M\&A transactions, exhibit less cash flow and profit volatility, and less idiosyncratic firm risk. Second, similar to legal environments which protect banks' interests better (Bae and Goyal, 2009), such

\footnotetext{
${ }^{10}$ However, the interests of employees and banks may diverge if the firm is close to insolvency. In general, banks prefer increasing liquidation value, whereas workers want to avoid liquidation and ensure going concern. However, the interests of banks may still be more aligned with those of employees, if compared to owners (who lose power relative to employees in PER firms). Furthermore, the German insolvency law aims at firm survival, and workers in Germany are comparatively well protected in case of insolvency due to state insurance (Ellul and Pagano, 2015). In case of insolvency, German law mandates that an insolvency administrator takes control of the firm; as the supervisory board has no control over the insolvency administrator, its power is very limited after insolvency application.

${ }^{11}$ Chen, Kacperczyk and Ortiz-Molina (2012) who find that firms in more unionized industries have lower bond yields also argue that workers may reduce the default probability.
} 
cross-monitoring may lead to more favorable financing conditions (e.g., lower interest rates and longer maturities). Less information asymmetry may also reduce the need for restrictive covenants ex-ante. Furthermore, direct bank ownership, which was not uncommon in Germany, is a substitute to cross-monitoring in this perspective (Gorton and Schmid, 2000). Regarding financial leverage, we expect that these supply side effects and lower (expected) cost of financial distress lead to higher financial leverage. Thus, higher leverage in this perspective is more an indirect consequence rather than a direct effect of employee representation.

To summarize, we examine three perspectives on how employee power may affect financial leverage. Both the bargaining and the interest alignment perspectives predict a higher financial leverage in firms with PER. However, the underlying mechanisms are different: we expect more favorable financing conditions and lower firm risk only for the interest alignment perspective; according to the bargaining perspective, we would expect no or even a negative effect on financing conditions due to above-optimal levels of debt. The job safety perspective predicts lower financial leverage. Which of these three perspectives dominates remains an empirical question.

\subsection{Empirical strategy}

Endogeneity is a major concern for empirical finance research in general (Roberts and Whited, 2013). In the context of corporate boards, the main concern is that their composition may be endogenously determined (e.g., Hermalin and Weisbach, 2003). Our identification strategy is twofold: first, we apply a regression discontinuity design around the threshold of 2,000 domestic employees. Second, we conduct a difference-in-differences analysis around the introduction of the law on codetermination. Neither of these two estimation methods is completely free of possible concerns. Thus, combining these different methods which both have their strengths and weaknesses enables us to better understand the causal impact of employee power on financial leverage. 


\subsubsection{Regression discontinuity design}

We first apply a regression discontinuity design (RDD). Such designs have been frequently applied in empirical finance research. A detailed discussion of this methodology is, among others, provided by Lee and Lemieux (2010). In this paper, we exploit for identification that German firms have to establish parity codetermination by law as soon as the number of domestic employees (DE) exceeds 2,000. This setting ensures that the establishment of parity codetermination is not a voluntary decision of the firms' owners or managers. ${ }^{12}$ Rather, German law mandates that

$$
\mathrm{PER}_{i, t}=\left\{\begin{array}{l}
1 \text { if } \mathrm{DE}_{i, t}>2000 \\
0 \text { if } \mathrm{DE}_{i, t} \leq 2000
\end{array}\right.
$$

where i indicates firms and t years. The law mandates that firms have to start the election process for a new supervisory board if they realize that they have crossed the threshold ( $\S 37$ MitbestG and $\S \S 97,98$ AktG). Because the final number of domestic employees is usually only known after the fiscal year and the complicated election process for employee representatives, there may be a small time lag between crossing the threshold and the actual board adjustment. Indeed, we find that 94.4 percent of our observations are in line with the law's regulations if we allow for an adjustment period of up to one year; with an adjustment period of up to two years, this increases to 96.2 percent. These figures show that the threshold variable and the PER status are nearly perfectly collinear, which allows us to estimate a standard RD model.

For the empirical estimation, we follow a parametric strategy and limit the sample to firms with around 2,000 domestic employees. For most tests, we use a range of 1,500 to 2,500 employees. The choice of this range is a tradeoff between accuracy and number of observations. This range results in 103 firms and 385 firm-years in our main models. Alternatively, we also apply narrower windows of up to \pm 100 domestic employees and conduct non-parametric, local estimation in the robust-

\footnotetext{
${ }^{12}$ Firms with up to 2,000 domestic employees could voluntarily establish parity codetermination. This is, however, very unlikely as it would require that the firms' owners voluntarily reduce their power on the supervisory board.
} 
ness Section 4.3. Our main model to estimate the causal effect of parity employee representation on leverage is

$$
\operatorname{Lev}_{i, t}=\kappa+\beta \cdot \mathrm{PER}_{i, t-1}+\tau_{t}+\vec{\nu} \cdot \vec{Z}_{i, t-1}+\sum_{p=1}^{4} \gamma_{p} \cdot A_{i, t-1}^{p}+\sum_{p=1}^{4} \delta_{p} \cdot A_{i, t-1}^{p} \cdot T_{0 \mid 1}+\epsilon_{i, t}
$$

where the assignment variable $A_{i, t-1}$ equals the number of domestic employees minus $2,000, \kappa$ is a constant, $Z_{i, t-1}$ is a vector of firm-specific, time-variant and timeconstant control variables (e.g., firm size and industry), and A is the assignment variable. In our case, this is the number of domestic employees minus 2,000, i.e., we center it at the threshold. We include the assignment variable as polynomials of degree four. This functional form controls for any direct impact of domestic employees on leverage around the threshold. Lastly, we interact the assignment variable with a dummy $\mathrm{T}$ which equals one if the number of domestic employees exceeds 2,000 to control for a potentially different effect of the number of domestic employees on leverage on both sides of the threshold. The coefficient which we are mainly interested in is $\beta$. This captures the discontinuous effect of parity employee representation on leverage at the threshold. Results can be found in Section 4.1. An important identification assumption is that firm do not precisely manipulate the threshold. For example, firms may strategically stay below or the threshold of 2,000 domestic employees. We discuss and test this assumption in Section 4.2.

To summarize, we focus on firms with between 1,500 and 2,500 domestic employees ("bandwidth"). We include the centered number of domestic employees up to polynomial four as controls ("functional form"). We also allow for a different functional form on both sides of the threshold. This functional form captures the continuous effect of the number of domestic employees ("assignment variable") on the outcome variable leverage. The discontinuous effect (i.e., the jump) at the threshold is thus captured by the coefficient for PER. 


\subsubsection{Difference-in-differences analysis}

For the difference-in-differences (DiD) analysis, we exploit the introduction of the law on codetermination in 1976. An important question in this context is why this law was introduced and whether there was lobbying. In line with the perspective that interests between banks and codetermined firms may be aligned (cf. Section 2.2), banks may have lobbied for the introduction of the law. Although this would not necessarily render our findings invalid, a more careful investigation of this potential identification concern is important.

The intellectual history of the law has three pillars: ${ }^{13}$ Socialist and Marxist ideas, the Catholic and Protestant church, and Liberalism. Inspired by socialist ideas which date back to the 19th Century in Germany, the concept of workers having a voice in firms' governance appeared in the party programs of the Christian Democratic Union (CDU) and the Social Democratic Party (SPD) shortly after World War II. Similar ideas were mentioned by the Catholic and Protestant Church. Representatives of liberalism also supported employee codetermination in the early 20th century, which had a strong influence on the 1971 party program of the Free Democratic Party (FDP). These three pillars led to a widespread thinking in Germany that workers should be given a voice in their firms. The political history of the law dates back at least to (unsuccessful) attempts to establish employee codetermination in the mid-19th century. Several decades later, a new trade regulation act under Wilhelm II and a law on works councils during the Weimar Republic (early 20th century) formed the starting point for employee codetermination in Germany. After World War II, the influence of unions increased substantially as they were needed for the rebuilding of the German industry. As reward for their efforts and cooperation, the unions demanded that employees should be given a voice in firms' governance. This finally led to the Montanmitbestimmungsgesetz in 1951 which mandates that supervisory boards in the Montan industry (e.g., iron and steel) must consist of an

\footnotetext{
${ }^{13}$ The description of history the law on codetermination follows Raiser, Veil and Jacobs (2015), pp. $2-5$.
} 
equal number of employee and owner representatives.

The general law on codetermination which we analyze in this paper goes back to the 1970s. A first draft for the law which would cover all industries was presented by the governing parties SPD and FDP in 1974. The law was passed by the German Parliament on March 18, 1976 and became effective on July 1, 1976. Regarding the threshold of 2,000 domestic employees, Raiser, Veil and Jacobs (2015) explain that the "political and scientific discussion considered mainly 1,000 to 2,000 employees, whereby the SPD, the CDU, and the DGB [German Federation of Trade Unions] considered 2,000 employees [...]" (p. 47) . Furthermore, they state that the reason for the final decision to use 2,000 employees was that only firms above that size have a sophisticated enough organizational structure to establish codetermination effectively. Thus, although we cannot completely rule out that there was bank political influence involved, there is little evidence that the law was passed due to lobbying activities, e.g., by large banks.

The legislator allowed for a two-year transition period. For most companies, the election of the supervisory board members had to follow the new law for the first time in 1978. During this introduction period, however, there was considerable uncertainty whether the law would persist as different parties (including employer associations) filed a constitutional complaint. They argued that the law would violate the German Constitution. On March 1, 1979, the German Constitutional Court ruled that the law was valid and affected firms had to implement parity codetermination accordingly. ${ }^{14}$ Thus, the introduction period starts in 1976 and ends in 1979. We analyze windows of plus/minus two, three, and four years around the introduction period; the introduction period itself is not considered. We define all firms which have introduced PER after the end of the introduction period as the treated group. The control group consists of firms which did not introduce PER

\footnotetext{
${ }^{14}$ By then, it was not clear how the court would decide. For instance, Wesel (2004) states that rarely a decision of the court was expected with such high tension. In a similar vein, the German news magazine "Spiegel" wrote on March 5, 1979 that German politicians were very excited before the court's decision and called the date "history-making" in the run-up. See Baums and Frick (1998) for more details on the court's decision.
} 
and firms related to the manufacturing of iron and steel, because codetermination was already established in 1951 for this so-called "Montan" industry. To reduce size differences between treated and control firms, we use an equal number of sizematched control firms (based on total assets in 1975) in our main specification. Alternative matching approaches are also presented. The applied DiD specification with firm-fixed effects is as

$$
\operatorname{Lev}_{i, t}=\alpha_{i}+\beta \cdot \text { Post }_{t} \cdot \operatorname{Treated}_{i}+\gamma \cdot \text { Post }_{t}+\delta \cdot \operatorname{Treated}_{i}+\tau_{t}+\vec{\nu} \cdot \vec{X}_{i, t-1}+\epsilon_{i, t},
$$

where $\operatorname{Lev}_{i, t}$ is the leverage of firm i in year t, $\alpha_{i}$ are firm-fixed effects, Post equals one after the year 1979 , Treated $i$ equals one for the treated group and zero for the control group, $\tau_{t}$ are year-fixed effects, $\vec{X}_{i, t-1}$ is a vector of firm-specific, time-variant control variables (e.g, firm size), and $\epsilon_{i, t}$ is the error term. Firm and year-fixed effects absorb the time-constant treated dummy as well as the post dummy in the empirical estimation. Results are presented in Section 4.6 and important assumptions for their validity such as parallel trends are tested in Section 4.7.

\section{Data}

\subsection{Sample construction}

Our main sample, which we use for the RD analysis, contains private and public German firms. It is based on data from Hoppenstedt $\mathrm{GmbH}$, a commercial provider of business information for German firms. For its compilation, we rely on data from their online database, which provides comprehensive coverage of the majority of German firms since 2005. We start with all medium-sized and large firms for which consolidated financial statements ("Konzernabschluss") are available. We exclusively focus on consolidated statements because the consolidated number of domestic employees is relevant for the law on codetermination ( $\$ 5$ MitbestG). Firms

without consolidated statements are ignored. In the case of business groups, we only consider the highest entity and exclude all other firms within that group, even 
if these other firms publish consolidated financial statements themselves; subsidiaries without consolidated financial statements would be automatically excluded in the previous step. We further drop firms from the financial service industry, those focusing on news reporting (because they they are exempt from the law), and stateowned enterprises.

Our identification strategy is based on the discontinuity around the threshold of 2,000 domestic employees. As explained in Section 2.3, most of our tests are conducted for firms with between 1,500 and 2,500 domestic employees. For the construction of this sub-sample, we have to identify the number of domestic employees for each firm-year. Although there is a data field for the number of total employees in the Hoppenstedt database, this information is often missing. Thus, we manually complete this information for firms which are likely relevant for our analysis. ${ }^{15}$ After that, we manually classify a firm's codetermination status and construct the dummy variable PER. As a last step, we drop firm-years in which the PER status changes and years with zero or negative equity. The final RDD sample of firms with between 1,500 and 2,500 domestic employees contains 385 firm-years from 103 firms between 2005 and 2013.

In addition to the $\mathrm{RD}$ analyses, we also investigate how leverage changed due to the introduction of the law on codetermiation. For this sample, we require data back to 1972 , i.e., four years before the introduction of the codetermination law in 1976 . The main data source for this sample is books - the so-called "Aktienführer" — which were published annually by Hoppenstedt or Saling since the 1950s. These books cover all companies with stocks traded at any exchange in Germany. Available information includes the firms' names, their business description, and basic balance sheet and profit and loss statement items (e.g, total assets, profit/loss, total debt

\footnotetext{
${ }^{15}$ In particular, we search for this number in annual reports for all firms with more than 1,000 and fewer than 6,000 total employees (because a fraction of less than about $50 \%$ domestic employees is not very common) if the information is missing. Firms' annual reports are obtained from their websites and from the Hoppenstedt database, which also includes reports from firms no longer in existence. As explained before, the consolidated number of domestic employees is relevant for the law; thus, we only consider consolidated statements and ignore unconsolidated statements.
} 
and equity). Most importantly for our purposes, the books also include the names of the firms' supervisory board members and their classification as owner or employee representative. ${ }^{16}$ From the universe of all firms covered by the books, we drop those which do not have their headquarters in Germany, financial firms, companies focusing on news reporting, firm-years with a change in the PER status, and firmyears with negative or zero equity. The final law introduction sample covers 1,380 firm-year observations from 203 firms between 1972 and 1983.

\subsection{Leverage and control variables}

Our main leverage measure is based on book values of debt and equity because the RDD sample also includes private firms. Thus, LEVERAGE is defined as total debt divided by total debt plus book value of equity. Total debt includes current and long-term liabilities and excludes provisions and accruals. Several control variables are included in our analysis. For all samples, we have information on firms' SIZE, which is defined as the natural logarithm of total assets, and ROA, defined as earnings divided by total assets. ${ }^{17}$ For the RDD sample, we have more detailed financial statement data, which allow us to construct several further control variables. TANGIBILITY is long-term tangible assets divided by total assets. As a proxy for growth opportunities, we include Tobin's Q (товQ). As our sample also covers private firms, we use the median of this variable in an industry and year. Furthermore, we also control for LISTING, which equals one for public firms and zero for private companies. In the German environment, both local or international GAAP are used. Thus, we include ACCOUNTING STANDARD, which equals one for international accounting standards. Industry-fixed effects are based on the Fama/French 38 industries classification. We winsorize the variables at the $1 \%$ and the $99 \%$ level to restrict the impact of outliers. Detailed definitions of all variables as well as their

\footnotetext{
${ }^{16}$ The annual versions of the book are accessed in digital form via the library of the University of Mannheim. We rely on extracted data from their database for the years 1979 and later. Before 1979, we hand-collect the required information from the books.

${ }^{17}$ Due to data constraints, we use net income for the law introduction sample and EBIT for the RDD sample.
} 
sources are shown in Appendix A. Descriptive statistics can be found in Table 1.

- Table 1 about here -

\section{Leverage}

\subsection{Regression discontinuity analysis}

Before we investigate the relationship between PER and leverage in a regression discontinuity design, we conduct a graphical evaluation. In Fig. 1 we first display the mean financial leverage for firms with between 1,500 to 2,500 domestic employees using bins of 50 employees. ${ }^{18}$ As PER is mandated by law for firms with more than 2,000 domestic employees, we expect a discontinuity at this threshold. Indeed, we find an increase in leverage if the number of domestic employees exceeds this threshold. This is true whether we use a quadratic (a) or a linear fitting (b) and we also observe a similar pattern when using bins of 100 instead of 50 employees in (c) and (d). Thus, these graphical evaluations provide a first indication that PER leads to higher financial leverage ratios.

- Fig. 1 about here -

The main regression discontinuity analysis is presented in Table 2. As explained in Section 2.3, we exploit that PER is required by law in firms with more than 2,000 domestic employees for identification. For the analysis, we use the RDD sample which covers firms with between 1,500 and 2,500 domestic employees. We indicate in each column of the table how we control for the number of domestic employees. We start with controlling for the centered number of domestic employees in Model I. In the next model, we include the centered number of domestic employees and the squared centered number as controls. Model III includes polynomials up to order two on both sides of the threshold. In the next model, we additionally control for

\footnotetext{
${ }^{18}$ For this figure, we exclude firm-years with more than 2,000 DE but no parity employee representation and those with up to 2,000 DE but parity employee representation. See the discussion on time lags in Section 2.3.1 for more details.
} 
several firm-specific factors like size or profitability. In the last model, we include polynomials up to order four on both sides of the threshold and additionally add interactions of the control variables with a dummy for more than 2,000 domestic employees. This allows for different effects of the controls on both sides of the threshold. In all models, we find strong and consistent evidence that PER increases financial leverage. The magnitude of this effect is slightly above 10 percentage points. Thus, the positive impact of PER on financial leverage is not only statistically significant, but also economically relevant. Overall, this finding is in line with the bargaining and interest alignment perspective.

An important aspect of any RD estimation is to check whether the covariates are balanced around the threshold. For this purpose, we use the controls as dependent variables in Panel $\mathrm{B}$ of Table 2. The insignificant results for PER indicate that there is no statistical evidence for a discontinuity of any control variable around the threshold. Thus, we conclude that discontinuous control variables are unlikely to bias our findings for PER.

\section{— Table 2 about here -}

\subsection{RDD: identification assumption}

An important identification assumption is that firms near the threshold are not precisely manipulating the number of domestic employees. One concern with this assumption in our setting may be that managers could have incentives to strategically stay below the threshold of 2,000 domestic employees to avoid PER. Although we cannot rule out that such manipulation would be theoretically possible, we follow Atanasov and Black (2016) and investigate whether there is any evidence that the threshold is indeed manipulated in practice.

An argument against actual manipulation in order to avoid PER is that this would imply that both the firm's owners and managers are willing to forgo future growth. We argue that this is not very plausible. Rather, owners and managers

are well aware that they cannot avoid codetermination if they want the firm to 
grow. Thus, there is no reason to strategically reduce firm growth just to postpone PER because the real option value of delaying growth is very small in this setting. Furthermore, large-scale strategic manipulation of firms to avoid PER is unlikely as the law is in place without major changes of its main elements since 1976. If there would be evidence for such behavior, it is very likely that the legislator would have adjusted the law. ${ }^{19}$

The empirical literature on labor regulation and firm size find that more stringent regulations can slow down firm growth. For example, Blanchard and Wolfers (2000), Botero et al. (2004), and Almeida and Carneiro (2009), among others, present evidence consistent with stronger labor rights causing firms to stay small, in order to avoid labor regulations that take effect if they grow to a certain size and/or to avoid taking on workers they cannot later fire. This evidence suggests that some manipulation in response to regulation may exist. With regard to size-based regulations and firm headcount growth, there is also some evidence for strategic behavior of firms (e.g., Schivardi and Torrini, 2008; Garicano, LeLarge and Van Reenen, 2013). However, most studies in this context analyze regulations that affect small firms (e.g., 15 or 50 employees). In our analysis, we focus on medium-sized and large firms for which manipulation of the threshold is likely more difficult because the incentives of owners and managers may not be aligned in these firms. Indeed, Kim, Maug and Schneider (2015) report that they detect no discontinuity around the threshold of 2,000 domestic employees in Germany.

We also perform a graphical evaluation to investigate whether there is a discontinuity in the distribution of domestic employees around 2,000 for our sample. If firms stay below the threshold to avoid PER, we would expect to see a disproportionally high number of firms just below the threshold and a low number above. We use a McCrary (2008) density test around the threshold to investigative the distribution

\footnotetext{
${ }^{19}$ In 2005, a Government Commission (the so-called "Biedenkopf" Commission) was set up to review the law on codetermination. Their final report summarizes that "academic members stated that they saw no reason to propose a fundamental revision of the German system of board-level representation", "the protection for employee interests provided by the existing regulations remains appropriate", and "only very few cases of companies avoiding board-level representation are known".
} 
of domestic employees around the threshold (see Fig. 2). We find no evidence for any significant discontinuity around 2,000 domestic employees. Thus, this graphical evaluation does not provide any indication for large-scale strategic manipulation of firms to avoid PER.

— Fig. 2 about here -

However, it may still be that some firm manipulate the threshold upwards, whereas others engage in downwards manipulation, which can create a smooth distribution around the threshold (Roberts and Whited, 2013). Thus, we additionally analyze firms in high-growth industries because firms in such environments are less likely able to precisely manipulate their number of employees, which creates "variation in treatment near the threshold [which] is randomized as though from a randomized experiment" (Lee and Lemieux, 2010, p. 283). High-growth industries are defined as those in which the growth over the past one or two years was higher than the median growth across all industries in the sample. As growth proxies, we analyze changes in sales, the total number of employees, and the number of domestic employees. The industry definition follows our main 38 industries specification. Results are reported in Panel A of Table 3. We find a strong and positive impact of PER on financial leverage in all different specifications. Thus, our finding is also valid for high-growth industries, in which the precise manipulation of firm size is less likely.

— Table 3 about here -

\subsection{RDD: bandwidth and estimation approach}

The choice of the RDD bandwidth is a trade-off between sample size and comparability of observations on both sides of the threshold. To alleviate concerns that our bandwidth choice biases the findings, we first follow suggestions in Angrist and Pischke (2008) and Atanasov and Black (2016) and investigate how the effect changes if we narrow the bandwidth. Both argue that the coefficient estimate should remain 
reasonably stable when reducing the bandwidth in a valid RDD setting. Results for narrower windows are shown in Panel B of Table 3. These alternative windows are $\pm 400, \pm 300, \pm 200$, and \pm 100 DE. Although the number of observations drops considerably, the coefficient for PER is positive and statistically highly significant for all alternative windows. Furthermore, it has a similar magnitude as in our main model. Thus, the positive effect of PER on financial leverage is not weaker if only firms near the cut-off point are considered, providing evidence for the validity of our RDD setting.

An alternative estimation approach is a non-parametric, local RD strategy (cf. Lee and Lemieux, 2010). One advantage of this method is that the optimal bandwidth can be automatically estimated, reducing concerns that arbitrarily chosen values bias the results. Furthermore, mainly observations close to the cutoff point are considered in this approach. Although this reduces our sample size considerably because the number of observations (very) close to the threshold of 2,000 is limited, we present this estimation approach as a robustness check. In particular, we apply local polynomial RD estimation with robust standard errors to analyze differences in leverage between observations slightly below and above the threshold (cf. Calonico, Cattaneo and Titiunik, 2014; Calonico et al., 2016). The bandwidth selection procedure is based on the mean square error optimal bandwidth selector. The results show that the outcome of the local strategy is very similar to our previously used approach.

\subsection{RDD: firm size}

Another concern may be that our results capture a general size effect. Although firms on the right-hand size of the threshold tend to be larger, it should be noted that we already control for the number of domestic employees in all models (up to polynomial four) to capture the discontinuous effect at the threshold.

To further mitigate such concerns, we start by performing placebo tests. If the prior results were not related to PER, but to a general effect due to an increase in the number of domestic employees, we would expect to find similar outcomes 
around other thresholds which have nothing to do with PER. We use 1,000, 1,500, 2,500 and 3,000 domestic employees as alternative thresholds for the placebo test in Panel $\mathrm{C}$ and restrict the sample to firm-years with threshold \pm 500 domestic employees. We find no indication that leverage changes significantly around these arbitrary thresholds. We also perform a placebo test with a threshold of 2,000 total employees. As explained before, the German law on codetermination focuses only on the number of domestic, not total employees. Consequently, we find no evidence that leverage changes around this threshold. Overall, these placebo tests provide further evidence that our prior result is indeed related to PER which is triggered by the threshold of 2,000 domestic employees.

Next, we perform a size matching approach in Panel D of Table 3. For this, we exploit that the assignment variable, i.e., the number of domestic employees is not perfectly correlated with traditional proxies for firm size like total assets. Furthermore, we do not expect any direct impact of the number of domestic employees on leverage, as this is not a commonly used control variable (Frank and Goyal, 2009). Empirically, we match treated (PER) and control firms (without PER) by total assets and calculate the average treatment effect (ATE). We apply propensity-score matching, nearest-neighbor matching, inverse-probability-weighted regression adjustment, and augmented inverse-probability weighted regression adjustment. The latter two approaches allow us to control for firm-level factors in the leverage regression. All models point at a positive effect of PER on leverage and the magnitude of the effect is comparable as in our main specifications. Thus, we conclude that differences in firm size between PER and non-PER firms are unlikely to bias our findings.

\subsection{RDD: general robustness tests}

As further robustness tests, we apply industry-year fixed effects instead of industry and year fixed effects (PER coefficient of 0.17, t-value of 3.21), restrict the sample to public firms (0.17, t-value of 2.38), and exclude the years 2008 and 2009 to avoid any bias due to the financial crisis (0.16, t-value of 3.83). We also find 
no evidence that the impact of PER is significantly different before and after the crisis. Lastly, to account for the fact that many firms in Germany are dominated by founding families (e.g., Ellul, Pagano and Panunzi, 2010), we control for family ownership (0.12, t-value of 2.53).

\subsection{Difference-in-differences analysis}

As an alternative identification strategy, we analyze the introduction of the law on codetermination in 1976 in a difference-in-differences setting. For this, we compare firms which were affected by the law's introduction, i.e., those with more than 2,000 domestic employees, with those which were not affected. An advantage here is that manipulation is less likely in this setting. Although we carefully examine the validity of our RDD setting, it is difficult to completely rule out this possibility in that context. Although still possible to some extent, manipulation of the PER status by either increasing or decreasing the number of domestic employees is a lesser concern for the DiD setting, mainly because the threshold of 2,000 was not largely expected and adjusting the number of employees takes time (see the discussion on anticipation effects in the next section for more details).

The details of the empirical methodology are described in Section 2.3. Results are presented in Table 4, Panel A. We start with windows of plus/minus two years around the introduction period in Model I, and move to four-year windows in Model III. All models include firm and time-fixed effects. Although the firm-fixed effects already control for time-constant firm-specific factors, we also add firm size and then additionally profitability as control variables. ${ }^{20}$ Across all specifications, we find consistent evidence that treated firms increased their financial leverage after the introduction of the law on codetermination. The economic magnitude of this effect is around five percentage points. Thus, this finding is in line with our RDD results.

— Table 4 about here -

\footnotetext{
${ }^{20}$ Due to data availability limitations, we cannot include more detailed control variables.
} 
A possible concern for the $\mathrm{DiD}$ analysis is the quality of German accounting data in the 1970s. Harris, Lang and Moller (1994) compare U.S. and German accounting data and find no significant differences regarding the information content of reported earnings. However, there is evidence that shareholder equity may be less informative in Germany. These possible flaws of the German accounting system may affect our findings because we rely on the book value of equity for our main leverage definition. Furthermore, the reported assets of firms may be biased. To mitigate these concerns, we first use market capitalization instead of total assets as proxy for firm size in Model IIId. Second, we replace our main leverage definition with market leverage, which is defined as total debt divided by the sum of total debt plus market value of equity in Model IV. Both alternative specifications lead to very similar results as our main models. Thus, flaws in the accounting figures are unlikely to bias our results.

To alleviate concerns that size differences between the treated and control groups bias our findings, we use an equal number of size-matched control firms in our main specifications. The matching is always based on firms' total assets in the pre-event year, i.e., 1975. We additionally present the outcome from alternative size-matching procedures in Panel B. In Model Va, we use all non-treated firms, irrespective of their size, as the control group. Treated and control firms are then matched based on propensity scores in Models $\mathrm{Vb}$ and $\mathrm{Vc}$. In the latter specification, we use a restrictive caliper of 0.06 , which equals approximately $20 \%$ of the standard deviation of the propensity score to further improve the balancing. We find similar results as before across all alternative specifications. Not surprisingly, we find strong size differences between treated and control firms when using all non-treated firms as controls in Model Va. These differences are much smaller when using the matching approaches and very close to zero in the last model (with no statistical evidence for any size difference). 


\subsection{DiD: anticipation and parallel trends}

Next, we test two important aspects in the context of DiD analyses: anticipation effects and trends before the event. We start with anticipation effects. Before 1974, there has only been a very vague suspicion that a law which may increase employee power could be introduced in the future, but it was neither clear how the details of such a law would look like nor whether such a law would come at all. In particular, the two ruling parties SPD and FDP were in disagreement regarding an increase in employee power. Thus, the first announcement that the government plans to introduce a new law on codetermination in early 1974 came as a surprise. This was also the first time that details like criteria of firms which would have to implement parity codetermination were officially announced. Later that year, a preliminary draft of the law was presented. In this setting, we consider it as unlikely that firms had enough time to perfectly manipulate their number of domestic employees in anticipation of the new law. Especially downward manipulation would have been difficult given the strict employee protection laws in Germany. A more feasible way to avoid codetermination may have been to relocate the company headquarters to another country, but this did not happen in large scale (Raiser, Veil and Jacobs, 2015, p. 35). Upward manipulation may also be possible, but this would require that owners and managers agree to have a suboptimal high staff number and thus lower profitability. Thus, we consider large-scale manipulation of the threshold unlikely in this setting, but we cannot completely rule out that some firms engaged in manipulation. To reduce concerns about anticipation effects before the law's introduction, we alternatively only use years before 1974 as pre-event period. Again, the results in Model VIa are very similar and even stronger than in our main specifications.

Another important identification assumption for difference-in-differences analysis is that there is no different development of the dependent variable in treated and control firms before the event ("parallel trends assumption"). To see whether this assumption is fulfilled, we investigate the time dynamics around the law change in Model VIb. We find no evidence for any difference in the development of financial 
leverage between both groups before the event. There is a strong difference between treated and control firms, but only after the law was introduced.

\section{Interest alignment}

Our main results are consistent with both the bargaining and the interest alignment perspective. To differentiate between these two, we first investigate how bank ownership affects the impact of PER on leverage. After that, we analyze the impact of PER on firms' interest rates and loan characteristics.

\subsection{Bank ownership}

If our results can be explained by an interest alignment effect, we expect that PER should be of minor importance if banks have other channels to directly influence firm policy. One such channel, which is not uncommon in the German environment, is bank ownership (Gorton and Schmid, 2000). Equity stakes enable banks to affect firm policy more effectively than being just debt providers, e.g., via a seat as firm owner in the supervisory board. Consequently, we hypothesize that the effect of PER is attenuated if a bank holds equity of the firm.

Our main empirical strategy to test this hypothesis is threefold: we start with analyzing the effect of bank ownership using the regression discontinuity design. After that, we focus on the interaction of PER with bank ownership based on firm-fixed

effects. Lastly, we circumvent the possible issue of endogenously determined bank ownership by using an exogenous event that reduced bank ownership in Germany: the capital gains tax reform in 2000. Data on bank ownership comes from annual versions of the Hoppenstedt books before 1997 and from CD-ROMs as well as direct data delivery from Hoppenstedt thereafter. Based on that data, we construct a dummy variable which indicates whether a bank owns voting right of the firm. For the test exploiting the tax event we focus on ownership by German banks as only these have been affected by the event.

Results for the RDD sample are presented in Table 5, Model Ia. We find that the positive impact of PER on leverage only exists for firms without bank ownership. 
If banks have other channels to influence firm policy, e.g., via direct ownership, employee codetermination seems to play no role. As next step, we focus on firms which changed their PER status between 1984 and 1998. This period is chosen because it does neither overlap with the analyses of the law's introduction nor the tax reform which will be exploited as third strategy. The results in Model IIa confirm the previous finding: if firms implement (abandon) PER, leverage goes up (down). This effect, however, is much less pronounced for firms with bank ownership. Here endogeneity concerns with regard to bank ownership are less severe as the main identification comes from legally mandated changes in PER over time.

\section{— Table 5 about here -}

To further mitigate concerns that endogenously determined bank ownership biases our findings in this context, we exploit a tax reform in 2000. This reform abolished capital gain taxes if corporates sold their equity stakes. Due to historical reasons, German banks often held large equity stakes in other German corporations; the origin of these holdings often dated back to the time after World War II (Edwards et al., 2004). Increases in the value of these equity stakes over time made it unattractive for banks to sell them before the tax reform. The reduction of equity holdings of banks companies, which were commonly regarded as a centerpiece of cross-links between German firms (also called "Deutschland AG") was one of the aims of the tax reform. As capital gains taxes could be close to $50 \%$ of the value of the equity holding before the reform, this represented a fundamental change and led to a wave of equity divestitures (Weber, 2009). The decline of bank ownership of public German firms is illustrated in Fig. 3.

- Fig. 3 about here -

The plans for a tax reform were first mentioned in late $1999 .{ }^{21}$ The abolishment

\footnotetext{
${ }^{21}$ The announcement of plans to reduce capital gains taxes led to a massive increase in stock prices of financial service companies. For instance, Edwards et al. (2004) report that stock prices climbed $18 \%$ for Munich Re, $13.6 \%$ for Deutsche Bank, and $12.9 \%$ for Allianz.
} 
of the capital gains tax took place on January 1, 2002. Thus, the event period is 1999 to 2001. We use four-year pre- and post-event windows (i.e., from 1995 to 1998 and 2002 to 2005). We focus on firms listed in the CDAX, the broadest German stock index, for this test because these are the firms for which domestic bank ownership is most likely. We are able to identify 62 companies with domestic bank ownership in the pre-event period, which form the sample for this test. For these firms, we obtain data on financial statements from Worldscope and identify their codetermination status based on Hoppenstedt's supervisory board data and firms' annual reports. We expect that firms with PER before the tax reform (i.e., in 1998) are less affected by the event because their codetermination status serves as substitute for bank ownership. Thus, PER firms are the treated group and nonPER firms the control group. We estimate a difference-in-differences model with firm-fixed effects around the tax reform. ${ }^{22}$

Results are presented in Model III of Table 5. We find that firms with bank ownership significantly reduced their leverage after the tax reform (Model IIIa). This effect, however, only exists for non-PER firms. Companies with codetermination exhibit no significant reduction in leverage after the event. ${ }^{23}$ The exogenous nature of the tax event makes it unlikely that endogeneity biases these findings. Overall, we find that interest alignment due to PER is of reduced importance when banks have a direct voice in the firm through their equity stakes. This provides evidence for a substitution effect between bank ownership and PER with regard to interest alignment.

An important aspect regarding banks and bank ownership in Germany is the proxy voting system ("Depotstimmrecht"). This system allows banks, with some restrictions, to exercise the votes of shares held for customers who do not want to exercise this right themselves (see, for instance, Baums, 1994). These are usually small private ("atomistic") shareholders. As a result, German banks often have

\footnotetext{
${ }^{22}$ We do not consider firms without domestic bank ownership as the event is unlikely to have any effect for these.

${ }^{23}$ Unreported results confirm that this finding also holds if year-fixed effects are included.
} 
more actual voting rights than their share ownership. We hypothesize that the substitution effect between bank ownership and employee codetermination should be different for firms with high and low levels of free float. Essentially, we use the level of free float to proxy for the likelihood and extent of proxy voting by banks. ${ }^{24}$ In firms with high levels of free float, banks are likely to have high voting rights independent of their actual share ownership due to the proxy voting system. Thus, direct bank ownership should be of minor importance for financial leverage, and in turn the substitution effect between PER and direct ownership by banks should be weak. In contrast, this substitution effect should mainly exist in firms with low free float, in which proxy voting plays no or a very minor role and banks need to rely on their direct voting rights.

As a validation test, we empirically test these predictions. For this, we define private firms and public firms with less than the median free float as low free float firms. Public firms with more than the median free float are high free float firms. We then estimate the previous models separately for these sub-samples. Results are reported in Table 5, Models (b) and (c). For all three test settings (RDD, firm-fixed effects, and the tax event), we find that the substitution effect between PER and bank ownership only exists for firms with low levels of free float. The coefficients on the interactions for the high free float samples are small and far from significant. Overall, this new test helps to validate our prior findings for bank ownership.

\subsection{Interest rate}

If there is an interest alignment between banks and firms with higher employee power, we further expect more favorable financing conditions for those firms. Thus we analyze firms' cost of debt and expect lower loan spreads for codetermined firms. As an empirical proxy for the cost of debt we use data on syndicated loans from

\footnotetext{
${ }^{24}$ The idea behind this measure is that "the votes of dispersed shareholders are concentrated in banks" (Gorton and Schmid, 2000, p. 48). For instance, Baums and Fraune (1995) find that banks had a majority during the shareholders' meeting in 20 of the 24 largest German companies with predominately widely held stocks, mainly because of proxy voting.
} 
Dealscan. ${ }^{25}$ Due to the limited number of firms using syndicated loans and because loan spreads are not always reported in Dealscan, the number of firms which we can use for this test is rather low. Thus, we do not impose any restrictions on the number of domestic employees for this test. This results in about 253 loans from 61 different firms. In addition to the control variables in the leverage models, we include controls for leverage and default risk. The latter is approximated by the Z-score. All firm-specific independent variables are lagged one year (i.e., they refer to the last available annual report before the loan). Furthermore, we also control for loan purpose and amount. Results are presented in Table 6. We first estimate a model without industry and year fixed effects. In the subsequent models, we include year-fixed and industry-fixed effects. All models provide consistent evidence that PER reduces cost of debt. ${ }^{26}$ The magnitude of cost of debt reduction is around 1.5 percent points in spread. Thus, the impact of PER on cost of debt is not only statistically significant, but also economically relevant.

— Table 6 about here -

\subsection{Loan characteristics}

Besides the spread, we also investigate other loan-level information from Dealscan. We focus on debt maturity and covenants. Based on the interest alignment hypothesis, we expect that PER increases debt maturity (Guedes and Opler, 1996). Results shown in Table 7 support this view. For covenants, we find that the number of covenants is on average lower for firms with parity employee representation. This is in line with our expectations as there are less incentive conflicts between codetermined firms and creditors. Overall, all these findings indicate that firms with PER have more favorable financing conditions and provide support for the view

\footnotetext{
${ }^{25}$ For this, we manually match the sample firms to Dealscan by firm name. For cost of debt we focus on the all-in-drawn spread (SPREAD).

${ }^{26}$ Morck, Nakamura and Shivdasani (2000) find Japanese firms more likely to be controlled by banks using more debt but paying higher interest costs and argue that main banks in Japan can, to a certain extent, strong-arm borrower firms into borrowing more and paying higher interest rates (Rajan, 1992). The lower interest rates documented in our setting likely suggest a more passive role for banks in Germany compared to those in Japan.
} 
that higher employee power increases interest alignment between borrowing firms and banks.

— Table 7 about here -

\section{Channels}

In this section we investigate firm risk as a possible channel for the interest alignment between banks and firms with PER. Risk-averse employees may have strong incentives to reduce firm risk due to their firm-specific human capital (Gorton and Schmid, 2000). If stronger employee power reduces firm risk, this would provide an intuitive explanation for lower agency conflicts between these firms and banks.

\subsection{Investments}

In general, mergers and acquisitions can increase or decrease firm-value. Debt providers, however, may dislike M\&A deals as they often increase firm complexity and managers' and owners' possibilities for self-utility maximizing behavior (e.g., empire building). Furthermore, M\&A deals can increase firm risk and reduce stability as the long-term success of such transactions is often highly uncertain. We collect data on M\&A deals for each sample year from SDC Platinum and match this information to our sample firms (based on firm names). ${ }^{27}$ Results are presented in Table 8. We include the same control variables as for leverage plus leverage itself. All independent variables are lagged one year (i.e., they are based on the last available annual report before the deal). We start by examining a dummy variable which indicates whether a firm conducted any M\&A deal in a specific year. After that, we investigate the annual number of deals a firm conducts. For both models, we find strong evidence that PER leads to significantly less M\&A activity. Thus, firms with stronger employee power tend to conduct fewer M\&A deals.

\footnotetext{
${ }^{27}$ In particular, we match the deals to the sample years based on their announcement dates and consider all announced deals.
} 
The next question we focus on is whether these firms select their M\&A targets more carefully. If employee representatives are effective monitors who reduce managerial agency cost, they may force managers to focus on value-increasing deals and avoid those related to their utility maximization. For this purpose, we analyze capital market reactions to the announcements of M\&A deals. In terms of methodology, we calculate cumulative abnormal returns (CAR) around the announcement dates. As event windows, we apply three days and use five days as robustness tests. Normal returns are estimated during the 200 trading days ending two months before the event. We use the CDAX as the market index. In addition, we also examine cumulative excess returns (CER), i.e., the returns of the firm which announces the deal above the market return. Results are reported in Table 8. We include two dummy variables which indicate whether the deal is diversifying or international. In Models IIa-IIc, we use the bandwidth of 1,500 to 2,500 DE, and in Models IIIa to IIIc, we run estimations using the larger bandwidth of 1,000 to 3,000 DE with industry fixed effects. Across all specifications, we find that the stock market reacts more positively to M\&A announcements of firms with PER. This is in line with the view that these firms tend to conduct value-increasing deals and avoid transactions that are related to utility maximization of managers.

— Table 8 about here -

\subsection{Cash flow stability}

We next investigate the stability of firms' cash flows and profits. If employee power leads to more stable business decisions, we expect less cash flow and profit fluctuation in firms with PER. We measure the standard deviation of cash flows and profits over firms' past three fiscal years. For the explanatory variables, we use the values as of the beginning of the respective window to focus on forward-looking stability and also control for sales growth. Results in Table 9, Model I provide evidence for more stability of cash flows and profits in firms with stronger employee power. Thus, these findings indicate that lower firm risk is a possible channel for the interest alignment between firms with codetermination and banks. 


\subsection{Idiosyncratic risk}

Besides the volatility of cash flows and profits, we also examine idiosyncratic firm risk. If firms with PER implement more stable investment and financial policies, we expect that these firms also have less idiosyncratic risk. To calculate idiosyncratic risk, we follow Panousi and Papanikolaou (2012). In particular, we calculate $\sigma_{i d i o}$. for each firm year based on weekly residuals of equity returns. The residuals are obtained from regressing the firm's equity returns on the CDAX as market return. $\sigma_{i d i o}$ for

firm i in year $\mathrm{t}$ is then calculated as $\sigma_{i d i o}^{i, t}=\sqrt{\sum_{\tau=1}^{52} \epsilon_{i, \tau}^{2}}$, where $\epsilon_{i, \tau}$ is the residual from the first regression in week $\tau$. More details can be found in Appendix A. Results in Model II of Table 9 show that parity codetermination reduces idiosyncratic risk. This further adds evidence that lower firm risk is a channel for the interest alignment effect between firms with PER and banks.

\section{Conclusion}

In this paper, we analyze how a direct voice of employees in firms' governance structure affects financial leverage. For this, we focus on a setting in which employees have a strong and direct influence on firms' policy: employee representatives in the supervisory boards of German firms. The supervisory board is comparable to the board of directors and has, among others, the duty to monitor the executive managers. This setting has two desirable features. First, the influence of employees is substantial: by law, the supervisory board of German firms has to consist of an equal number of employee and owner representatives (parity employee representation, PER). Second, the law's design provides an identification strategy because it only applies to firms with more than 2,000 domestic employees. Using a regression discontinuity design around this threshold and a difference-in-differences analysis around the introduction of the law in 1976 for identification we find strong evidence that PER increases leverage. Combining these two different methods which both are 
not completely free of concerns enables us to better understand the causal impact of employee codetermination on financial leverage.

Our setting differs from the existing literature on employee power and financial leverage along two dimensions. First, we analyze how a direct voice of employees in the firms' governance structure affects financial leverage. Prior literature in this area focuses on indirect influence of labor, e.g., via labor unions or employee protection. Second, power is shifted from owners to employees by law. We analyze three perspectives on how employee power can affect leverage in this setting: bargaining, employment protection, and interest alignment.

We find strong support for the interest alignment perspective. Employee representatives who aim to protect the interests of the firm's employees may (unintentionally) also help to protect the interests of banks as both stakeholders are interested in the long-term survival and stability of the firm. In line with this explanation, we find that bank ownership and PER act as substitutes. As bank ownership may be endogenous, we also exploit the capital gains tax reform of 2000 as an exogenous shock to banks' equity holdings. Further analyses also reveal that firms with PER enjoy more favorable financing conditions, i.e., lower cost of debt, longer debt maturities, and fewer covenants. Lastly, we identify lower firm risk due to codetermination as possible channel for this interest alignment effect. In particular, firms with strong employee power conduct fewer and better M\&A deals, have more stable cash flows and profits, and have lower idiosyncratic risk.

Behind the background of a steady shift from indirect employee representation via labor unions to more direct forms of employee influence (Wilkinson et al., 2014), our results have important implications. Most importantly, we show that the consequences of direct employee influence can be very different from those of an indirect influence. Thus, the results for indirect employee influence, which has been the main focus of the literature on labor and finance, may not necessarily be applicable to more direct forms of labor voice. In particular, our findings indicate that a direct voice of employees in firms' governance structure can be a powerful mecha- 
nism to reduce agency conflicts between debt providers and firms and to improve their financing opportunities and conditions. Revealing the mechanism of how direct employee influence affects corporate decision making may support policy makers to advance and improve regulations on how employees can express their voice in firms' governance structure.

Our findings raise the question whether firms can also profit by voluntarily granting employees such a direct voice or whether this requires a stringent legal framework. Although this cannot be definitively answered by this paper, we speculate that a positive effect on financing requires at least a strong commitment of the firm to such rights. Otherwise, the possibility that firms divest employees of their rights in certain situations, e.g., changes in the ownership structure, may wipe out the positive effects of direct employee voice for financing. A more detailed investigation on the situations in which direct employee influence improves financing conditions is a promising area for future research. More generally, further investigations of the impact of employee representation on optimal board composition (e.g., Weisbach, 1988) or the role of the board (e.g., Morck, Shleifer and Vishny, 1989) may also help to further our understanding of the consequences of a direct employee voice. 


\section{References}

Almeida, R., Carneiro, P., 2009. Enforcement of labor regulation and firm size. Journal of Comparative Economics 37, 28-46.

Angrist, J. D., Pischke, J.-S., 2008. Mostly harmless econometrics: An empiricist's companion. Princeton University Press.

Atanasov, V., Black, B., 2016. Shock-based causal inference in corporate finance and accounting research. Critical Finance Review, forthcoming.

Atanassov, J., Kim, E. H., 2009. Labor and corporate governance: International evidence from restructuring decisions. Journal of Finance 64, 341-374.

Bae, K.-H., Goyal, V. K., 2009. Creditor rights, enforcement, and bank loans. Journal of Finance 64, 823-860.

Bae, K.-H., Kang, J.-K., Wang, J., 2011. Employee treatment and firm leverage: A test of the stakeholder theory of capital structure. Journal of Financial Economics 100, 130-153.

Baums, T., 1994. The German banking system and its impacts on corporate finance and governance. In: Aoki, M., Patrick, H. (Eds.), The Japanese Main Bank System: Its Relevance for Developing and Transforming Economies. Oxford University Press.

Baums, T., Fraune, C., 1995. Institutionelle Anleger und Publikumsgesellschaft: Eine empirische Untersuchung. Die Aktiengesellschaft 3, 97-112.

Baums, T., Frick, B., 1998. Co-determination in Germany: the impact of court decisions on the market value of firms. Economic Analysis 1, 143-161.

Benelli, G., Loderer, C., Lys, T., 1987. Labor participation in corporate policymaking decisions: West Germany's experience with codetermination. Journal of Business 60, 553-575.

Berk, J. B., Stanton, R., Zechner, J., 2010. Human capital, bankruptcy, and capital structure. Journal of Finance 65, 891-926.

Berk, J. B., Van Binsbergen, J. H., Liu, B., 2014. Matching capital and labor. Unpublished Working Paper.

Blanchard, O., Wolfers, J., 2000. The role of shocks and institutions in the rise of European unemployment: the aggregate evidence. The Economic Journal 110, 1-33. 
Botero, J. C., Djankov, S., La Porta, R., Lopez de Silanes, F., Shleifer, A., 2004. The regulation of labor. Quarterly Journal of Economics 119, 1339-1382.

Bronars, S. G., Deere, D. R., 1991. The threat of unionization, the use of debt, and the preservation of shareholder wealth. Quarterly Journal of Economics 106, $231-254$.

Calonico, S., Cattaneo, M. D., Farrell, M. H., Titiunik, R., 2016. rdrobust: Software for regression discontinuity designs. Unpublished Working Paper.

Calonico, S., Cattaneo, M. D., Titiunik, R., 2014. Robust nonparametric confidence intervals for regression-discontinuity designs. Econometrica 82, 2295-2326.

Campbell, T. S., Kracaw, W. A., 1980. Information production, market signalling, and the theory of intermediation. Journal of Finance 35, 863-882.

Chemmanur, T. J., Cheng, Y., Zhang, T., 2013. Human capital, capital structure, and employee pay: An empirical analysis. Journal of Financial Economics 110, $478-502$.

Chen, H. J., Kacperczyk, M., Ortiz-Molina, H., 2012. Do nonfinancial stakeholders affect the pricing of risky debt? Evidence from unionized workers. Review of Finance 16, 347-383.

Datta, S., Iskandar-Datta, M., Patel, A., 1999. Bank monitoring and the pricing of corporate public debt. Journal of Financial Economics 51, 435-449.

Diamond, D. W., 1991. Monitoring and reputation: The choice between bank loans and directly placed debt. Journal of Political Economy 99, 689-721.

Edwards, C. H., Lang, M. H., Maydew, E. L., Shackelford, D. A., 2004. Germany's repeal of the corporate capital gains tax: The equity market response. Journal of the American Taxation Association 26, 73-97.

Ellul, A., Pagano, M., 2015. Strategic leverage and employee protection in bankruptcy. Unpublished Working Paper.

Ellul, A., Pagano, M., Panunzi, F., 2010. Inheritance law and investment in family firms. American Economic Review 100, 2414-2450.

Ellul, A., Pagano, M., Schivardi, F., 2015. Employment and wage insurance within firms: Worldwide evidence. Unpublished Working Paper.

Faleye, O., Mehrotra, V., Morck, R., 2006. When labor has a voice in corporate governance. Journal of Financial and Quantitative Analysis 41, 489-510. 
Fauver, L., Fuerst, M. E., 2006. Does good corporate governance include employee representation? Evidence from German corporate boards. Journal of Financial Economics 82, 673-710.

FitzRoy, F. R., Kraft, K., 1993. Economic effects of codetermination. Scandinavian Journal of Economics 95, 365-375.

Frank, M. Z., Goyal, V. K., 2009. Capital structure decisions: which factors are reliably important? Financial Management 38, 1-37.

Freeman, R., 1991. Employee councils, worker participation, and other squishy stuff. In: Proceedings of the 43rd annual meeting of the Industrial Relations Research Association. Madison, WI: Industrial Relations Research Association.

Freeman, R. B., Lazear, E. P., 1995. An economic analysis of works councils. In: Rogers, J., Streeck, W. (Eds.), Works Councils: Consultation, Representation, and Cooperation in Industrial Relations. University of Chicago Press.

Freeman, R. B., Rogers, J., 1993. Who speaks for us? Employee representation in a nonunion labor market. In: Kaufman, B., Kleiner, M. (Eds.), Employee representation: Alternatives and future directions. Madison, WI: Industrial Relations Research Assocation.

Garicano, L., LeLarge, C., Van Reenen, J., 2013. Firm size distortions and the productivity distribution: Evidence from France. NBER Working Paper No. 18841.

Ginglinger, E., Megginson, W., Waxin, T., 2011. Employee ownership, board representation, and corporate financial policies. Journal of Corporate Finance 17, 868-887.

Gorton, G., Schmid, F. A., 2000. Universal banking and the performance of German firms. Journal of Financial Economics 58, 29-80.

Gorton, G., Schmid, F. A., 2004. Capital, labor, and the firm: A study of German codetermination. Journal of the European Economic Association 2, 863-905.

Graham, J. R., Kim, H., Li, S., Qiu, J., 2015. The labor impact of corporate bankruptcy. Unpublished Working Paper.

Guedes, J., Opler, T., 1996. The determinants of the maturity of corporate debt issues. Journal of Finance 51, 1809-1833.

Guiso, L., Pistaferri, L., Schivardi, F., 2005. Insurance within the firm. Journal of Political Economy 113, 1054-1087. 
Harris, T. S., Lang, M., Moller, P. H., 1994. The value relevance of german accounting measures: An empirical analysis. Journal of Accounting Research 32, 187-209.

Hermalin, B. E., Weisbach, M. S., 1998. Endogenously chosen boards of directors and their monitoring of the CEO. American Economic Review 88, 96-118.

Hermalin, B. E., Weisbach, M. S., 2003. Boards of directors as an endogenously determined institution: A survey of the economic literature (digest summary). Economic Policy Review 9, 7-26.

Jensen, M. C., Meckling, W. H., 1976. Theory of the firm: Managerial behavior, agency costs and ownership structure. Journal of Financial Economics 3, 305360 .

Jensen, M. C., Meckling, W. H., 1979. Rights and production functions: An application to labor-managed firms and codetermination. Journal of Business 52, 469-506.

Kim, E. H., Maug, E., Schneider, C., 2015. Labor representation in governance as an insurance mechanism. Unpublished Working Paper.

Kim, E. H., Ouimet, P., 2014. Broad-based employee stock ownership: Motives and outcomes. Journal of Finance 69, 1273-1319.

Lee, D. S., Lemieux, T., 2010. Regression discontinuity designs in economics. Journal of Economic Literature 48, 281-355.

Matsa, D. A., 2010. Capital structure as a strategic variable: Evidence from collective bargaining. Journal of Finance 65, 1197-1232.

McCrary, J., 2008. Manipulation of the running variable in the regression discontinuity design: A density test. Journal of Econometrics 142, 698-714.

Morck, R., Nakamura, M., Shivdasani, A., 2000. Banks, ownership structure, and firm value in Japan. Journal of Business 73, 539-567.

Morck, R., Shleifer, A., Vishny, R. W., 1989. Alternative mechanisms for corporate control. American Economic Review 79, 842-852.

Pagano, M., Volpin, P. F., 2005. Managers, workers, and corporate control. Journal of Finance 60, 841-868.

Panousi, V., Papanikolaou, D., 2012. Investment, idiosyncratic risk, and ownership. Journal of Finance 67, 1113-1148. 
Perotti, E. C., Spier, K. E., 1993. Capital structure as a bargaining tool: The role of leverage in contract renegotiation. American Economic Review 83, 1131-1141.

Raiser, T., Veil, R., Jacobs, M., 2015. Mitbestimmungsgesetz und Drittelbeteiligungsgesetz (De Gruyter Kommentar), 6th Edition. De Gruyter.

Rajan, R. G., 1992. Insiders and outsiders: The choice between informed and arm'slength debt. Journal of Finance 47, 1367-1400.

Ratti, R. A., 1980. Bank attitude toward risk, implicit rates of interest, and the behavior of an index of risk aversion for commercial banks. Quarterly Journal of Economics 95, 309-331.

Rieble, V., 2006. Schutz vor paritätischer Unternehmensmitbestimmung. BetriebsBerater 37, 2018-2023.

Roberts, M., Whited, T., 2013. Endogeneity in empirical corporate finance. In: Constantinides, G., Harris, M., Stulz, R. (Eds.), Handbook of the Economics of Finance. Vol. 2. Elsevier, pp. 493-572.

Schivardi, F., Torrini, R., 2008. Identifying the effects of firing restrictions through size-contingent differences in regulation. Labour Economics 15, 482-511.

Schwartz-Ziv, M., Weisbach, M. S., 2013. What do boards really do? Evidence from minutes of board meetings. Journal of Financial Economics 108, 349-366.

Simintzi, E., Vig, V., Volpin, P. F., 2015. Labor protection and leverage. Review of Financial Studies 28, 561-591.

Stein, J. C., 1989. Efficient capital markets, inefficient firms: A model of myopic corporate behavior. Quarterly Journal of Economics 104, 655-669.

Svejnar, J., 1981. Relative wage effects of unions, dictatorship and codetermination: econometric evidence from Germany. Review of Economics and Statistics 63, 188197.

Svejnar, J., 1982. Codetermination and productivity: Empirical evidence from the Federal Republic of Germany. In: Jones, D. C., Svejnar, J. (Eds.), Participatory and Self-managed Firms: Evaluating Economic Performance. Lexington Books.

Weber, A., 2009. An empirical analysis of the 2000 corporate tax reform in Germany: Effects on ownership and control in listed companies. International Review of Law and Economics 29, 57-66. 
Weisbach, M. S., 1988. Outside directors and CEO turnover. Journal of Financial Economics 20, 431-460.

Wesel, U., 2004. Der Gang nach Karlsruhe. K. Blessing.

Wilkinson, A., Dundon, T., Donaghey, J., Freeman, R., 2014. Employee voice: charting new terrain. In: Handbook of research on emplyoee voice. Edward Elgar Publishing, pp. 3-16.

Williamson, S. D., 1987. Costly monitoring, loan contracts, and equilibrium credit rationing. Quarterly Journal of Economics 102, 135-145. 
Fig. 1. This figure shows regression discontinuity plots with quadratic (a, c) or linear (b, d) fits and the corresponding $90 \%$ confidence intervals. The $\mathrm{x}$-axis displays the number of domestic employees, measured in bins of 50 or 100 employees around 2,000. Positive (negative) values indicate firms with (without) PER. The y-axis shows the mean leverage in the respective bin.

(a) bins of 50, quadratic fit

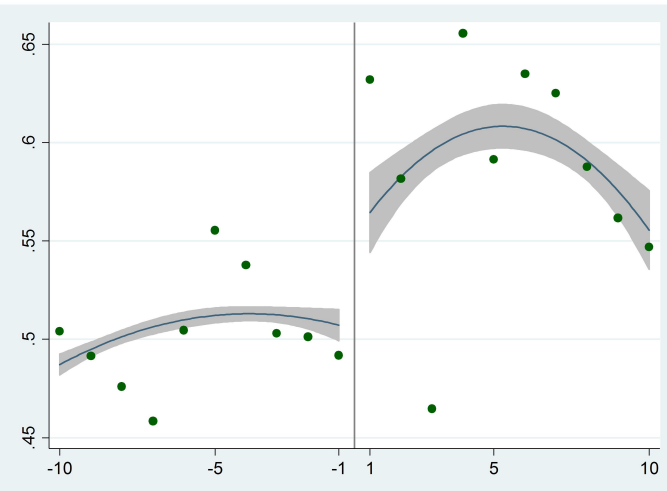

(c) bins of 100, quadratic fit

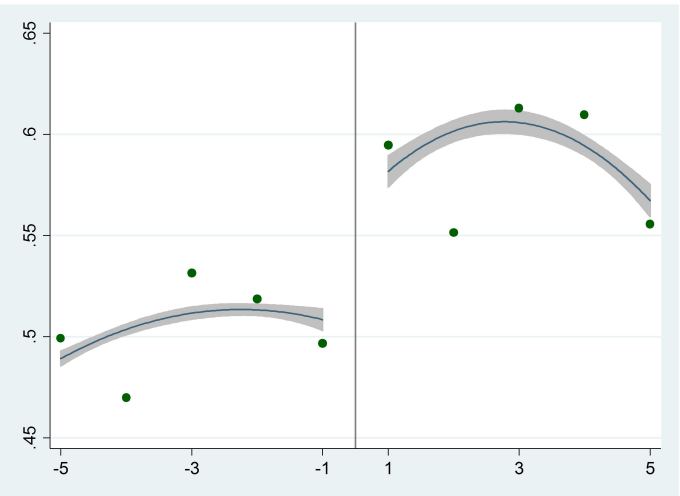

(b) bins of 50, linear fit

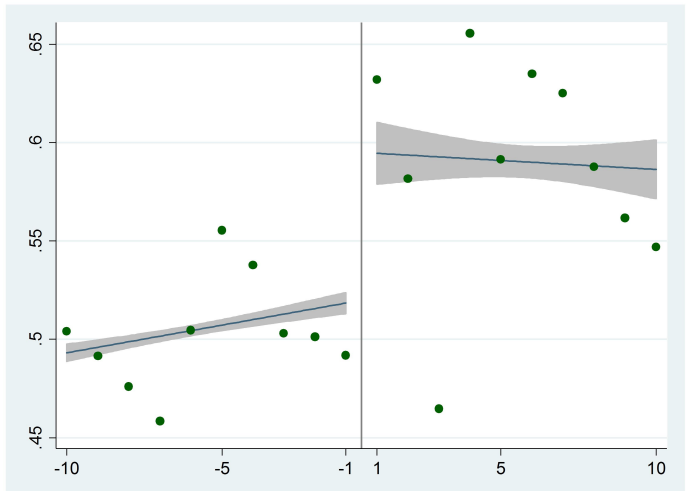

(d) bins of 100, linear fit

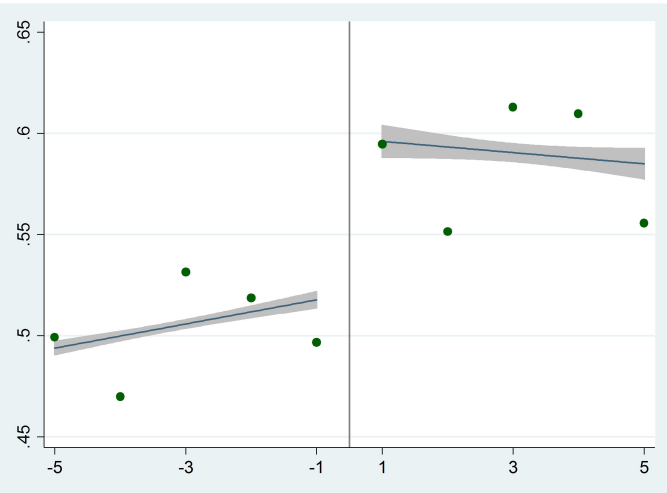


Fig. 2. This figure shows the McCrary (2008) density test for domestic employees around the threshold of 2,000 domestic employees. The density function is estimated for the full sample. The graph is based on the "DCdensity" function in Stata and default values are used for the bandwidth and bin size.

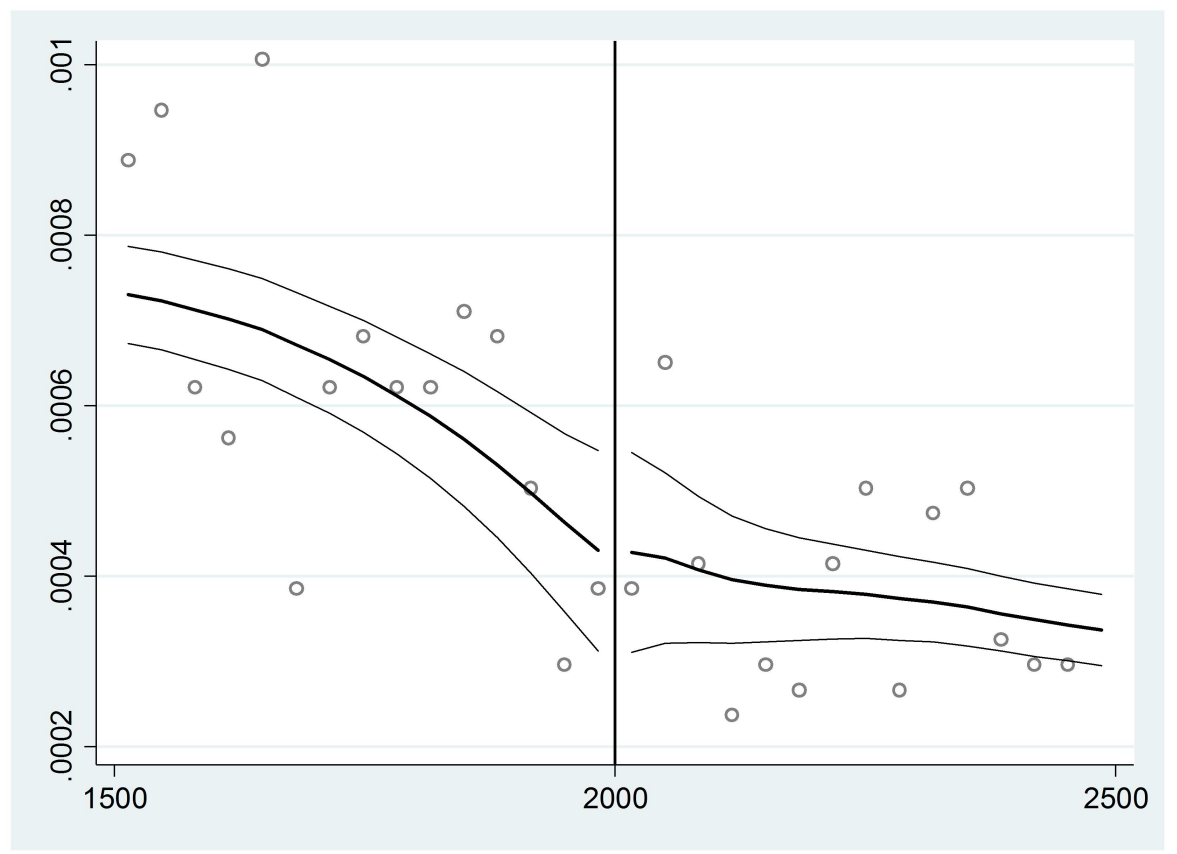

Fig. 3. This figure shows bank ownership before and after the tax reform. The vertical axis represents the average ownership of German banks in firms listed in the CDAX.

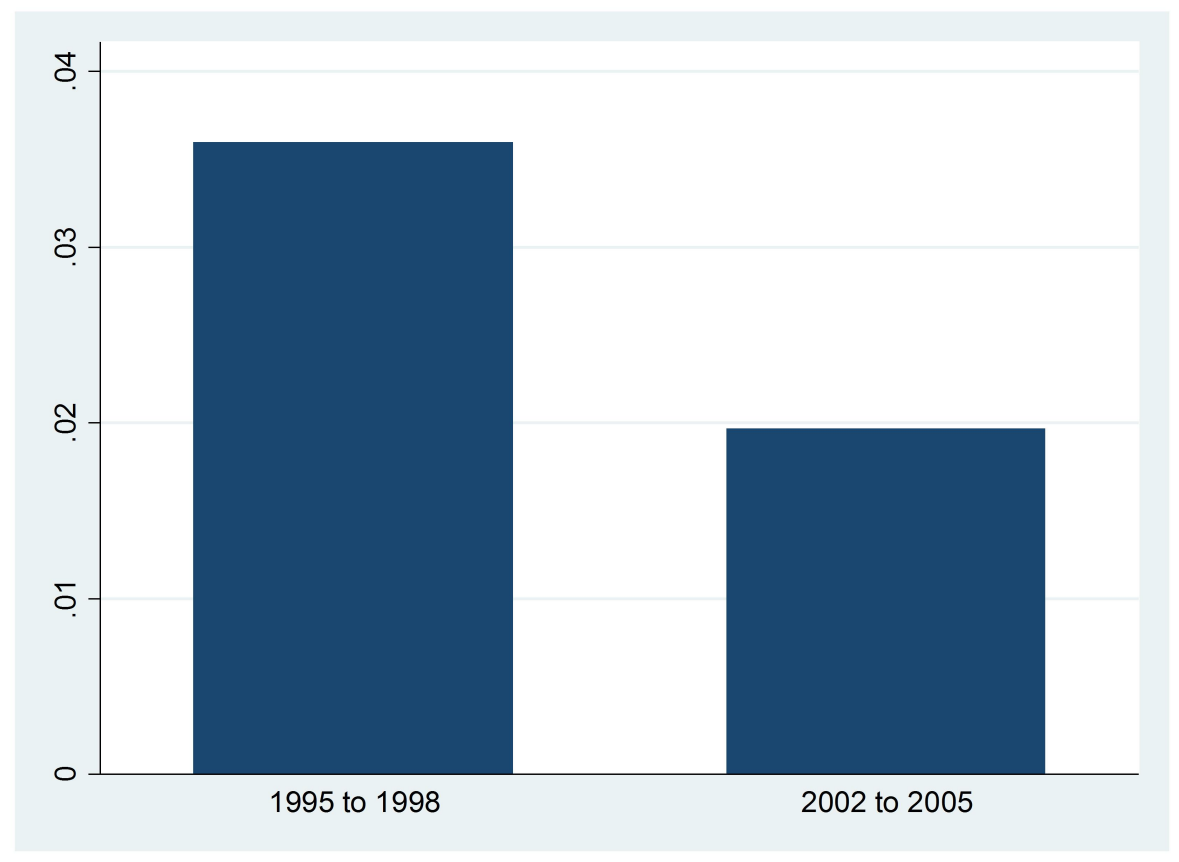


Table 1

Descriptive statistics

This table presents the number of observations (N), mean, standard deviation (SD), $25 \%$ percentile, median, and $75 \%$ percentile values for the main variables used in the paper. Panel A displays the descriptive statistics for the regression discontinuity sample. Here, only firm-years with $\geq 1,500$ and $\leq 2,500$ domestic employees are considered. Panel B focuses on the law introduction sample, which covers the years 1972 to 1983 . A detailed description of all variables can be found in Appendix A.

\begin{tabular}{lcccccc}
\hline Variable & N & Mean & SD & p25 & p50 & p75 \\
\hline Panel A: RDD & sample & (2005 & to $\mathbf{2 0 1 3})$ & & \\
\hline PER & 385 & 0.26 & 0.44 & 0 & 0 & 1 \\
DE & 385 & 1882 & 276 & 1644 & 1842 & 2063 \\
Leverage & 385 & 0.52 & 0.20 & 0.39 & 0.56 & 0.64 \\
Size (mio Eur) & 385 & 620 & 612 & 263 & 440 & 704 \\
ROA & 385 & 0.08 & 0.07 & 0.04 & 0.08 & 0.12 \\
Tangibility & 385 & 0.33 & 0.19 & 0.20 & 0.30 & 0.41 \\
TobQ $i n d$ & 385 & 1.31 & 0.34 & 1.11 & 1.22 & 1.45 \\
Listing & 382 & 0.38 & 0.49 & 0 & 0 & 1 \\
Acc. Std. & 385 & 0.47 & 0.50 & 0 & 0 & 1 \\
\hline Panel B: Law introduction sample & $(\mathbf{1 9 7 2}$ & to & $\mathbf{1 9 8 3})$ \\
\hline Treated & 1380 & 0.45 & 0.50 & 0 & 0 & 1 \\
Leverage & 1380 & 0.65 & 0.17 & 0.58 & 0.67 & 0.76 \\
Size (mio Eur) & 1378 & 760 & 1929 & 62 & 152 & 573 \\
ROA & 1361 & 0.09 & 2.19 & 0.01 & 0.02 & 0.04 \\
\hline
\end{tabular}


Table 2

Regression discontinuity analysis

In Panel A, the dependent variable is LEVERAGE. PER stands for parity employee representation and equals one for firms with parity codetermination. All models are pooled OLS regressions. Independent variables except accounting standard and listing are lagged one period. Firm-years with between 1,500 and 2,500 domestic employees are included. Polynomial indicates how we control for the centered number of domestic employees. Either side means that polynomials interacted with a dummy for $>2,000 \mathrm{DE}$ are included. Controls $\mathrm{x}>\mathrm{DE}_{2,000}$ indicates whether firm control variables interacted with a dummy for $>2,000 \mathrm{DE}$ are included. In Panel B, the controls are used as dependent variables to examine whether they are balanced around the threshold. The model specifications follow Panel A, Model V. T-statistics based on Huber/White robust standard errors clustered by firms are presented in parentheses. $* * *, * *$ and $*$ indicate significance on the $1 \%-, 5 \%$ - and $10 \%$-levels, respectively. A detailed description of all variables can be found in Appendix A.

\begin{tabular}{|c|c|c|c|c|c|}
\hline \multicolumn{6}{|c|}{ Panel A: Leverage around threshold } \\
\hline Model & I & II & III & IV & $\mathrm{V}$ \\
\hline PER & $\begin{array}{c}0.11^{* *} \\
(2.59)\end{array}$ & $\begin{array}{c}0.11^{* *} \\
(2.60)\end{array}$ & $\begin{array}{c}0.11^{* *} \\
(2.52)\end{array}$ & $\begin{array}{c}0.14 * * * \\
(3.77)\end{array}$ & $\begin{array}{c}0.14 * * * \\
(3.31)\end{array}$ \\
\hline Size & & & & $\begin{array}{c}-0.0044 \\
(-0.12)\end{array}$ & $\begin{array}{l}-0.011 \\
(-0.24)\end{array}$ \\
\hline $\mathrm{ROA}$ & & & & $\begin{array}{c}-0.80 * * * \\
(-3.64)\end{array}$ & $\begin{array}{c}-0.85^{* * *} \\
(-3.97)\end{array}$ \\
\hline Tangibility & & & & $\begin{array}{c}-0.23 \\
(-1.38)\end{array}$ & $\begin{array}{c}-0.17 \\
(-0.81)\end{array}$ \\
\hline TobQ ${ }_{\text {ind }}$ & & & & $\begin{array}{l}0.029 \\
(0.66)\end{array}$ & $\begin{array}{l}0.022 \\
(0.39)\end{array}$ \\
\hline Listing & & & & $\begin{array}{l}0.050 \\
(0.78)\end{array}$ & $\begin{array}{l}0.058 \\
(0.67)\end{array}$ \\
\hline Acc. Std. & & & & $\begin{array}{c}-0.14^{* *} \\
(-2.51)\end{array}$ & $\begin{array}{c}-0.18^{* * *} \\
(-2.65)\end{array}$ \\
\hline Observations & 357 & 357 & 357 & 345 & 345 \\
\hline Firms & 100 & 100 & 100 & 97 & 97 \\
\hline Adj. $R^{2}$ & 0.28 & 0.27 & 0.27 & 0.37 & 0.42 \\
\hline Industry/Year FE & yes & yes & yes & yes & yes \\
\hline Polynomial & one & two & two & two & four \\
\hline / either side & no & no & yes & yes & yes \\
\hline Controls $\mathrm{x}>\mathrm{DE}_{2,000}$ & no & no & no & no & yes \\
\hline
\end{tabular}

Panel B: Covariates around threshold

\begin{tabular}{lccccc}
\hline Dep. variable & Size & ROA & Tangibility & Listing & Acc. Std. \\
\hline PER & $\mathbf{0 . 3 5}$ & $\mathbf{- 0 . 0 1 9}$ & $\mathbf{0 . 0 0 1 3}$ & $\mathbf{0 . 1 5}$ & $\mathbf{0 . 1 4}$ \\
& $\mathbf{( 1 . 5 6 )}$ & $\mathbf{( - 0 . 8 4 )}$ & $\mathbf{( 0 . 0 2 9 )}$ & $\mathbf{( 1 . 2 1 )}$ & $\mathbf{( 1 . 0 4 )}$ \\
\hline Observations & 351 & 351 & 351 & 348 & 351 \\
Industry/Year FE & yes & yes & yes & yes & yes \\
\hline
\end{tabular}


Table 3

Regression discontinuity: alternative specifications and matching

The dependent variable is LEVERAGE. PER stands for parity employee representation and equals one for firms with parity codetermination. Firm-years with between 1,500 and 2,500 domestic employees are included, if not stated otherwise. The non-reported controls follow Table 2. We control for the centered number of domestic employees up to polynomial two on both sides of the threshold. In Panel A, only high-growth industries are considered. High-growth industries are those industries in which the growth over the past one or two years was higher than the median growth across all industries in the sample. Growth is either measured as sales, total staff, or domestic employees growth. The industry definition follows the Fama/French 38 industries classification. In Panel $B$, we present alternative RDD specifications with narrower windows of domestic employees around the threshold of 2,000 DE. We also apply a local polynomial RD estimator with robust bias-corrected standard errors and a MSE-optimal bandwidth selector. For these models, we use contemporaneous instead of lagged independent variables. Panel $C$ presents placebo tests with arbitrary thresholds around domestic (DE) or total employees (TE). These models include firmyears with \pm 500 domestic employees. In Panel D, we present size matching based on propensityscore matching (PSC), nearest-neighbor (NN) with (n) neighbors, or inverse-probability-weighted regression adjustment (IPWRA) and augmented inverse-probability weighted regression adjustment (AIPW) models with control variables. ATE stands for the average treatment effect. Firm size as measured by total assets is the matching variable. ***, ** and * indicate significance on the $1 \%-$, $5 \%$ - and 10\%-levels, respectively. A detailed description of all variables can be found in Appendix A.

\begin{tabular}{|c|c|c|c|c|c|c|}
\hline \multicolumn{7}{|c|}{ Panel A: High growth industries } \\
\hline & \multicolumn{2}{|c|}{ sales growth } & \multicolumn{2}{|c|}{ staff growth } & \multicolumn{2}{|c|}{ DE growth } \\
\hline & one year & two years & one year & two years & one year & two years \\
\hline PER & $\begin{array}{c}0.18^{* * *} \\
(3.67)\end{array}$ & $\begin{array}{c}0.19 * * * \\
(3.54)\end{array}$ & $\begin{array}{c}0.13^{* *} \\
(2.17)\end{array}$ & $\begin{array}{c}0.16^{* *} \\
(2.50)\end{array}$ & $\begin{array}{c}0.17^{* *} \\
(2.06)\end{array}$ & $\begin{array}{c}0.14^{* *} \\
(2.24)\end{array}$ \\
\hline Controls & yes & yes & yes & yes & yes & yes \\
\hline Observations & 174 & 170 & 171 & 164 & 172 & 165 \\
\hline \multicolumn{7}{|c|}{ Panel B: Bandwidth } \\
\hline & $\pm 400 \mathrm{DE}$ & $\begin{array}{l}\text { alternative } \\
\pm 300 \mathrm{DE}\end{array}$ & $\begin{array}{l}\text { bandwidth } \\
\pm 200 \mathrm{DE}\end{array}$ & $\pm 100 \mathrm{DE}$ & \multicolumn{2}{|c|}{$\begin{array}{l}\text { optimal bandwidth } \\
\text { local polynomial RD }\end{array}$} \\
\hline PER & $\begin{array}{c}0.14^{* * *} \\
(2.99)\end{array}$ & $\begin{array}{c}0.13 * * * \\
(2.81)\end{array}$ & $\begin{array}{c}0.11^{*} \\
(1.90)\end{array}$ & $\begin{array}{c}0.15^{* * *} \\
(2.87)\end{array}$ & $\begin{array}{l}0.18^{*} \\
(1.70)\end{array}$ & $\begin{array}{c}0.18^{* * *} \\
(3.30)\end{array}$ \\
\hline Controls & yes & yes & yes & yes & no & yes \\
\hline Observations & 288 & 208 & 134 & 62 & 78 & 82 \\
\hline \multicolumn{7}{|c|}{ Panel C: Placebo tests } \\
\hline & $1,000 \mathrm{DE}$ & $1,500 \mathrm{DE}$ & $2,500 \mathrm{DE}$ & $3,000 \mathrm{DE}$ & $2,000 \mathrm{TE}$ & \\
\hline $\operatorname{Dummy}_{D E / T E}$ & $\begin{array}{l}-0.030 \\
(-0.70)\end{array}$ & $\begin{array}{l}-0.029 \\
(-0.73)\end{array}$ & $\begin{array}{l}-0.020 \\
(-0.40)\end{array}$ & $\begin{array}{l}-0.033 \\
(-0.86)\end{array}$ & $\begin{array}{l}-0.048 \\
(-1.08)\end{array}$ & \\
\hline Controls & yes & yes & yes & yes & yes & \\
\hline Observations & 540 & 495 & 221 & 173 & 288 & \\
\hline
\end{tabular}

continued on next page 
Table 3 continued

\begin{tabular}{|c|c|c|c|c|c|c|}
\hline \multicolumn{7}{|c|}{ Panel D: Size matching } \\
\hline & PSC & $\mathrm{NN}(1)$ & $\mathrm{NN}(2)$ & $\mathrm{NN}(3)$ & IPWRA & AIPW \\
\hline ATE (PER) & $\begin{array}{c}0.092^{* *} \\
(2.18)\end{array}$ & $\begin{array}{c}0.094^{* *} \\
(2.32)\end{array}$ & $\begin{array}{c}0.095^{* *} \\
(2.45)\end{array}$ & $\begin{array}{c}0.091 * * \\
(2.19)\end{array}$ & $\begin{array}{c}0.11^{* * *} \\
(3.79)\end{array}$ & $\begin{array}{c}0.075 * * * \\
(3.35)\end{array}$ \\
\hline Controls & no & no & no & no & yes & yes \\
\hline Observations & 352 & 352 & 352 & 352 & 340 & 340 \\
\hline
\end{tabular}


Table 4

Difference-in-differences analysis

The dependent variable is LEVERAGE, if not stated otherwise. All models are firm-fixed effects regressions. Panel $A$ investigates the introduction of the law on codetermination. The German parliament passed the law on May 4, 1976 and it became effective on July 1 with a two-year transition period. The introduction period ends with the decision of the German Federal Constitutional Court to reject a constitutional complaint and its ruling that the the law was valid on March 1, 1979. Firms which introduced PER during this introduction period are TREATED. POST intr $_{\text {equals one }}$ after 1979. The pre- and post-event periods around the introduction period are indicated in each column. Control firms are dropped based on their total assets (in 1975) until the numbers of control and treated firms are equal. TREATED and POSTintr are absorbed by firm and year-fixed effects. Panel $B$ presents alternative specifications for the $[-4,+4]$ period. In Model IV, the dependent variable is market leverage, which is defined as total debt divided by the sum of total debt plus market value of equity. We use all control firms in Model Va or conduct propensity score nearest neighbor matching without replacement based on total assets (in 1975) in Model Vb; in Model Vc, we apply a more restrictive caliper of 0.06 (about $20 \%$ of the SD of the propensity score). The years 1974 and 1975 are not considered as pre-event period in Model VIa. Model VIb shows the dynamics around the introduction period with -2y denoting the year 1974, -1y the year 1975, 1y the year 1980, and $2 \mathrm{y}+$ years after 1980, respectively. T-statistics based on Huber/White robust standard errors clustered by firms are presented in parentheses. $* * *, * *$ and $*$ indicate significance on the 1\%-, 5\%- and 10\%-levels, respectively. A detailed description of all variables can be found in Appendix A.

\begin{tabular}{|c|c|c|c|c|c|c|}
\hline \multicolumn{7}{|c|}{ Panel A: Introduction of the law on codetermination } \\
\hline Model & I & II & IIIa & IIIb & IIIc & IIId \\
\hline Window [years] & {$[-2,+2]$} & {$[-3,+3]$} & {$[-4,+4]$} & {$[-4,+4]$} & {$[-4,+4]$} & {$[-4,+4]$} \\
\hline Treated x Post & $\begin{array}{c}0.042^{* *} \\
(2.21)\end{array}$ & $\begin{array}{c}0.045^{* *} \\
(2.34)\end{array}$ & $\begin{array}{c}0.052^{* * *} \\
(2.62)\end{array}$ & $\begin{array}{c}0.039 * * \\
(2.26)\end{array}$ & $\begin{array}{c}0.039 * * \\
(2.29)\end{array}$ & $\begin{array}{c}0.044^{* *} \\
(2.23)\end{array}$ \\
\hline Size (total assets $[\ln ]$ ) & & & & $\begin{array}{c}0.058^{* * *} \\
(5.27)\end{array}$ & $\begin{array}{c}0.059^{* * *} \\
(5.31)\end{array}$ & \\
\hline Size (market cap $[\ln ])$ & & & & & & $\begin{array}{c}0.0060 \\
(0.43)\end{array}$ \\
\hline $\mathrm{ROA}$ & & & & & $\begin{array}{l}-0.013 \\
(-0.13)\end{array}$ & $\begin{array}{c}-0.20 * * \\
(-2.03)\end{array}$ \\
\hline Observations & 692 & 1,037 & 1,380 & 1,191 & 1,174 & 1,160 \\
\hline Firms & 194 & 195 & 203 & 195 & 195 & 193 \\
\hline Adj. $R^{2}$ & 0.063 & 0.052 & 0.060 & 0.16 & 0.17 & 0.069 \\
\hline Year FE & yes & yes & yes & yes & yes & yes \\
\hline Firm FE & yes & yes & yes & yes & yes & yes \\
\hline
\end{tabular}


Table 4 continued

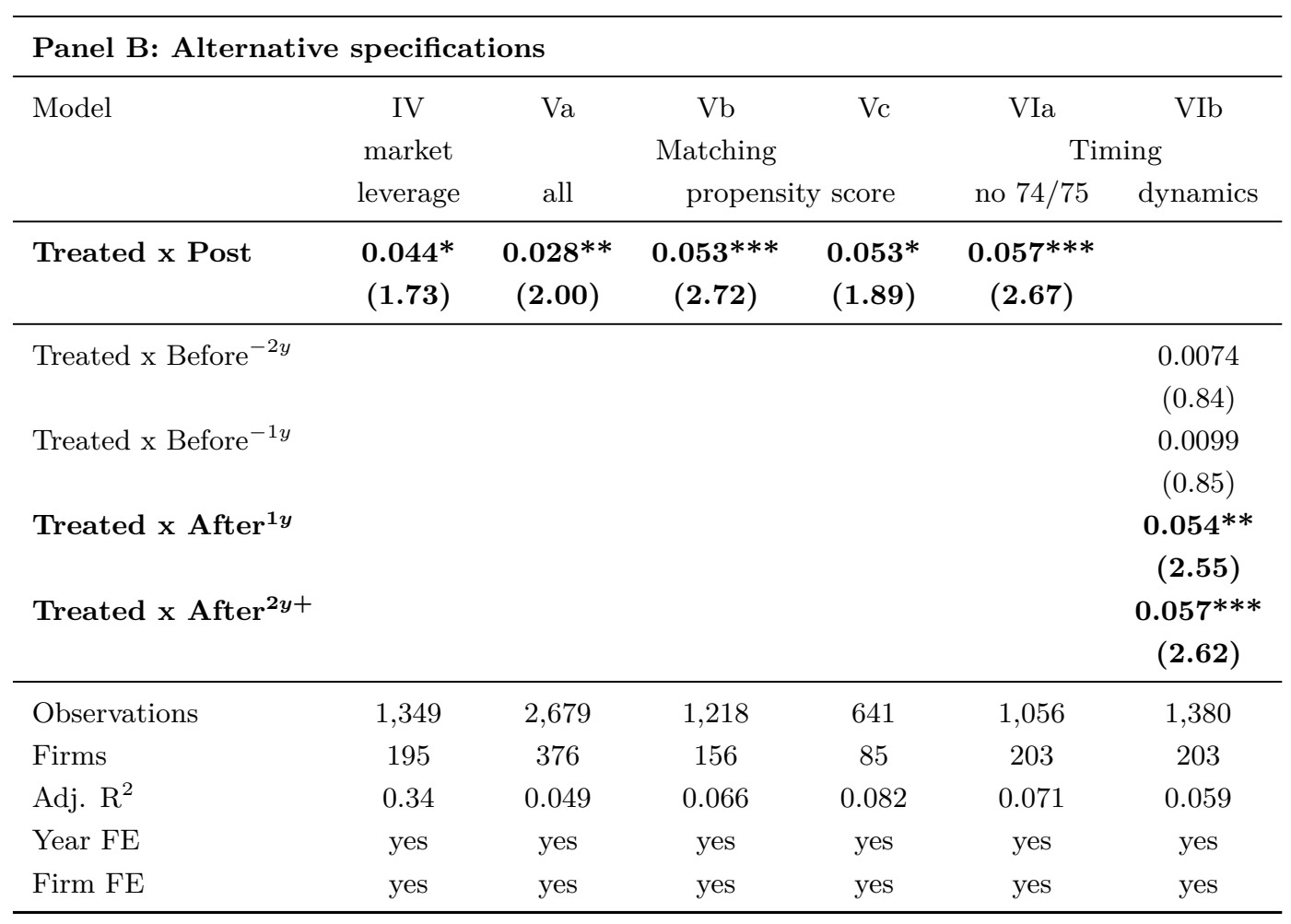




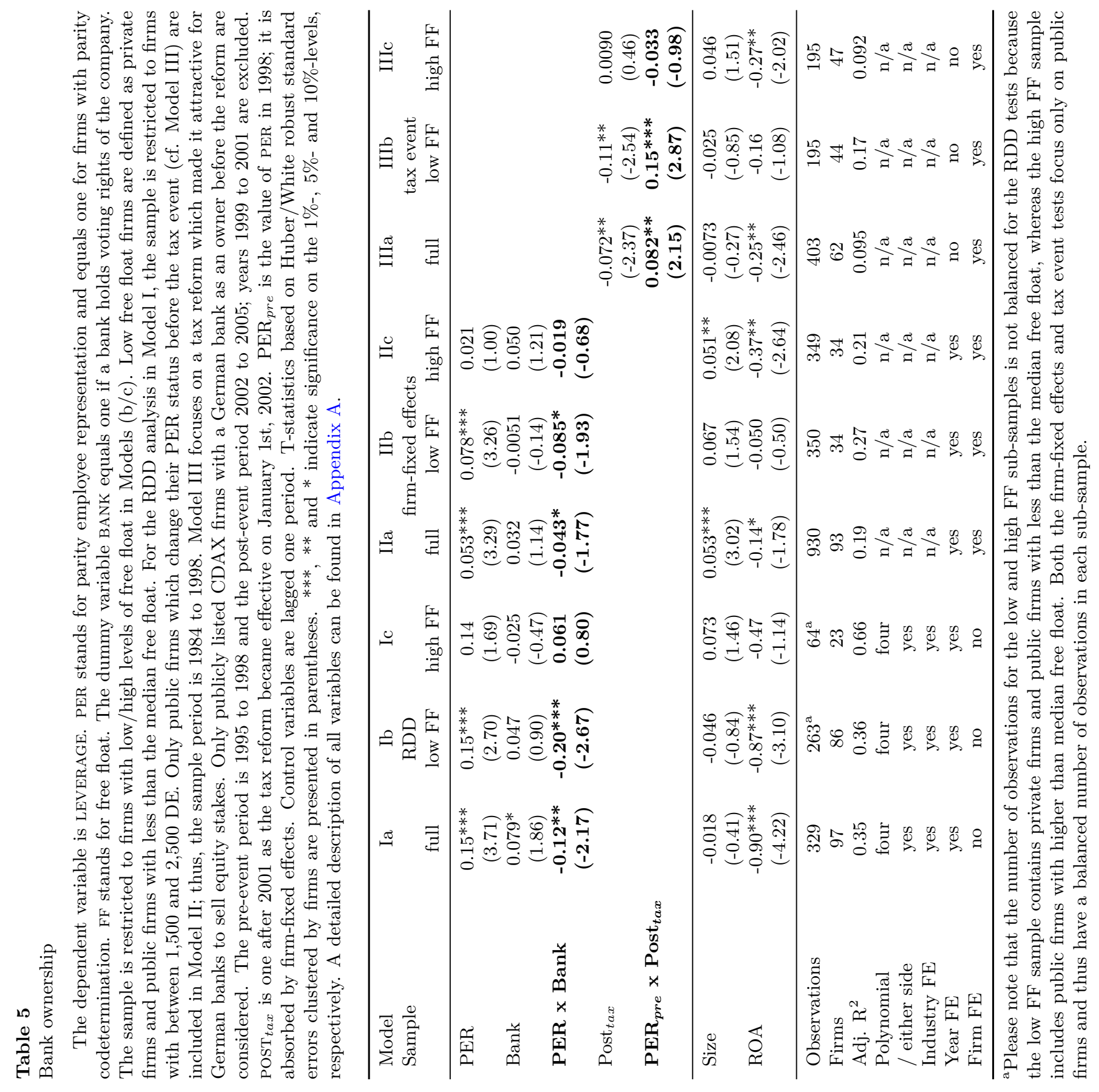


Table 6

Interest rate

The dependent variable is SPREAD of syndicated loans. PER stands for parity employee representation and equals one for firms with parity codetermination. All models are pooled OLS regressions. Independent variables are lagged one period. All firm-years are considered. Deal controls include PuRPOSE and AmOUNT. T-statistics based on Huber/White robust standard errors clustered by firms are presented in parentheses. $* * *, * *$ and $*$ indicate significance on the $1 \%-, 5 \%$ - and $10 \%$-levels, respectively. A detailed description of all variables can be found in Appendix A.

\begin{tabular}{|c|c|c|c|}
\hline Model & I & II & III \\
\hline PER & $\begin{array}{c}-0.018^{* * *} \\
(-3.38)\end{array}$ & $\begin{array}{c}-0.013^{* * *} \\
(-3.05)\end{array}$ & $\begin{array}{c}-0.018^{* * *} \\
(-3.52)\end{array}$ \\
\hline Leverage & $\begin{array}{c}0.00065 \\
(0.090)\end{array}$ & $\begin{array}{r}0.0050 \\
(1.06)\end{array}$ & $\begin{array}{r}0.0060 \\
(0.86)\end{array}$ \\
\hline Size & $\begin{array}{c}-0.0036^{* *} \\
(-2.51)\end{array}$ & $\begin{array}{c}-0.0053^{* * *} \\
(-4.62)\end{array}$ & $\begin{array}{c}-0.0018 \\
(-1.54)\end{array}$ \\
\hline Tangibility & $\begin{array}{c}-0.0050 \\
(-0.58)\end{array}$ & $\begin{array}{c}0.00060 \\
(0.11)\end{array}$ & $\begin{array}{c}0.030^{* *} \\
(2.45)\end{array}$ \\
\hline $\mathrm{ROA}$ & $\begin{array}{l}-0.014 \\
(-0.54)\end{array}$ & $\begin{array}{c}-0.017^{*} \\
(-1.79)\end{array}$ & $\begin{array}{c}-0.039^{* *} \\
(-2.42)\end{array}$ \\
\hline TobQ ${ }_{\text {ind }}$ & $\begin{array}{c}-0.0058 \\
(-1.41)\end{array}$ & $\begin{array}{c}-0.00018 \\
(-0.11)\end{array}$ & $\begin{array}{r}0.0042 \\
(0.95)\end{array}$ \\
\hline Listing & $\begin{array}{c}0.00066 \\
(0.29)\end{array}$ & $\begin{array}{c}-0.00026 \\
(-0.15)\end{array}$ & $\begin{array}{l}0.0028 \\
(1.17)\end{array}$ \\
\hline Z-score class & $\begin{array}{c}-0.0019 \\
(-0.70)\end{array}$ & $\begin{array}{c}-0.0013 \\
(-0.80)\end{array}$ & $\begin{array}{r}-0.0027 \\
(-1.45)\end{array}$ \\
\hline Observations & 253 & 253 & 253 \\
\hline Firms & 61 & 61 & 61 \\
\hline Adj. $R^{2}$ & 0.37 & 0.59 & 0.63 \\
\hline Industry FE & no & no & yes \\
\hline Year FE & no & yes & yes \\
\hline Deal controls & yes & yes & yes \\
\hline Polynomial & four & four & four \\
\hline / either side & yes & yes & yes \\
\hline
\end{tabular}


Table 7

Loan characteristics

The dependent variables is $\ln$ (maturity) in Model Ia, maturity in Model Ib, and number of covenants in Model II. PER stands for parity employee representation and equals one for firms with parity codetermination. All firm-years are considered. Model Ia is a pooled OLS regression; Models Ib and II are Poisson regressions. Independent variables are lagged one period. Deal controls include PURPOSE and AMOUNT. T-statistics based on Huber/White robust standard errors clustered by firms are presented in parentheses. ${ }^{* * *}, * *$ and $*$ indicate significance on the $1 \%$-, $5 \%$ - and $10 \%$-levels, respectively. A detailed description of all variables can be found in Appendix A.

\begin{tabular}{|c|c|c|c|}
\hline \multirow[t]{2}{*}{ Model } & $\mathrm{Ia}$ & $\mathrm{Ib}$ & \multirow{2}{*}{$\begin{array}{c}\text { II } \\
\text { covenants }\end{array}$} \\
\hline & \multicolumn{2}{|c|}{ maturity } & \\
\hline \multirow[t]{2}{*}{ PER } & $0.16^{*}$ & $0.16^{*}$ & $-3.63 * *$ \\
\hline & $(1.70)$ & $(1.71)$ & $(-2.21)$ \\
\hline \multirow[t]{2}{*}{ Leverage } & 0.094 & -0.010 & 4.35 \\
\hline & $(0.44)$ & $(-0.055)$ & $(0.91)$ \\
\hline \multirow[t]{2}{*}{ Listing } & $0.090 * *$ & $0.096^{* * *}$ & 0.22 \\
\hline & $(2.60)$ & $(3.31)$ & $(0.45)$ \\
\hline \multirow[t]{2}{*}{ Size } & $0.41^{* *}$ & $0.25^{*}$ & $10.2^{* *}$ \\
\hline & $(2.23)$ & $(1.74)$ & $(2.29)$ \\
\hline \multirow[t]{2}{*}{ Tangibility } & $0.80^{*}$ & $0.66^{*}$ & 8.48 \\
\hline & $(1.85)$ & $(1.66)$ & $(0.82)$ \\
\hline \multirow[t]{2}{*}{ ROA } & 0.12 & 0.15 & 0.58 \\
\hline & $(0.94)$ & $(1.35)$ & $(0.55)$ \\
\hline \multirow[t]{2}{*}{ TobQ $i n d$} & -0.072 & -0.079 & $4.18^{* *}$ \\
\hline & $(-1.18)$ & $(-1.56)$ & $(2.56)$ \\
\hline \multirow[t]{2}{*}{ Z-score class } & 0.0030 & -0.0072 & -1.58 \\
\hline & $(0.048)$ & $(-0.13)$ & $(-1.52)$ \\
\hline Observations & 733 & 733 & 761 \\
\hline Firms & 132 & 132 & 133 \\
\hline Adj. $R^{2}$ & 0.16 & $\mathrm{n} / \mathrm{a}$ & $\mathrm{n} / \mathrm{a}$ \\
\hline Industry FE & yes & yes & yes \\
\hline Year FE & yes & yes & yes \\
\hline Deal controls & yes & yes & yes \\
\hline Polynomial & four & four & four \\
\hline / either side & yes & yes & yes \\
\hline
\end{tabular}




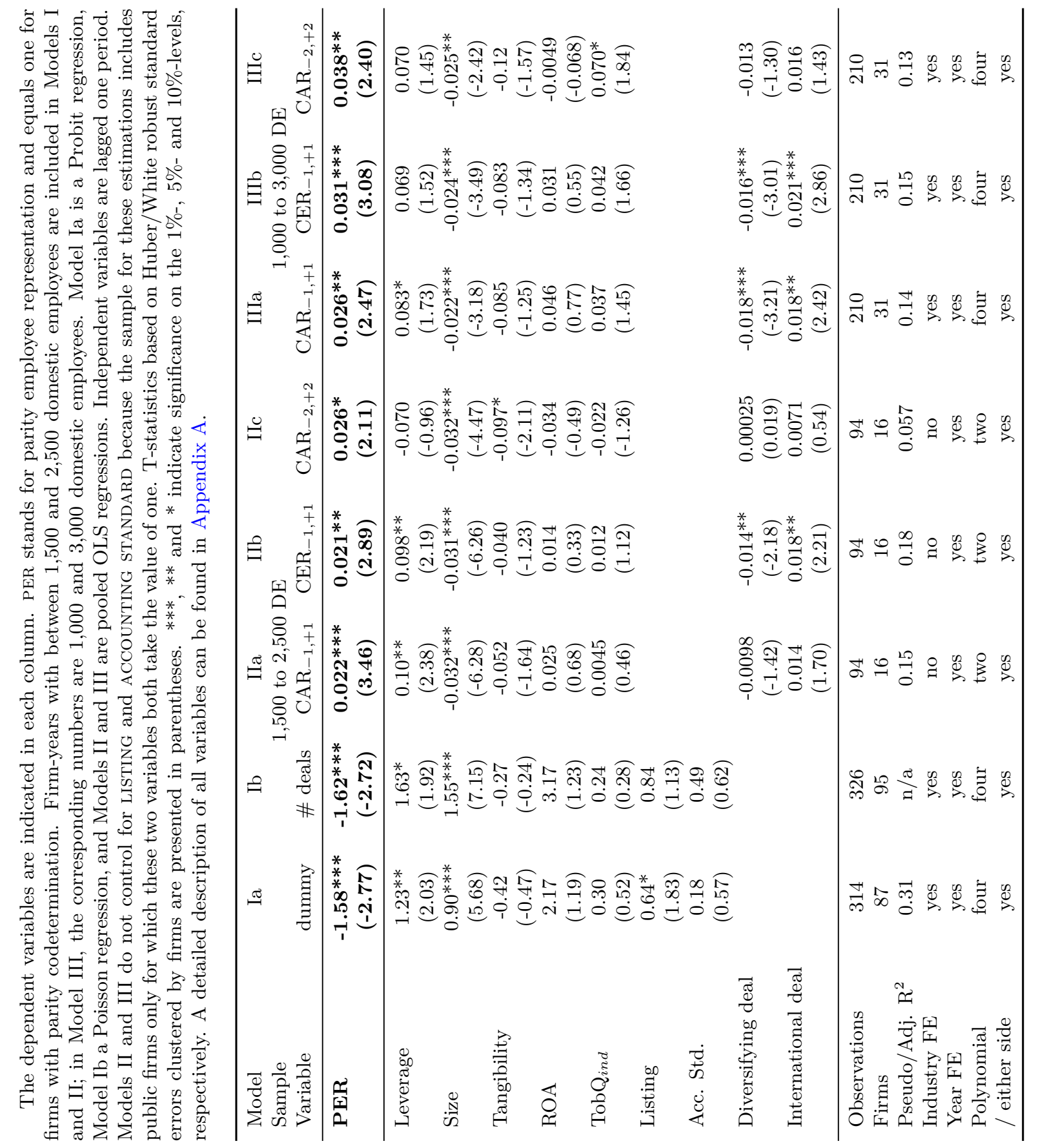




\section{Table 9}

Stability and risk

The dependent variables are indicated in each column. PER stands for parity employee representation and equals one for firms with parity codetermination. $\sigma$ (cash flow) and $\sigma$ (ROA) measure the standard deviation of cash flow (scaled by total assets) and return on assets over the past three fiscal years. $\sigma_{i d i o}$ is a yearly measure for idiosyncratic risk based on weekly equity returns. Firm-years with between 1,500 and 2,500 domestic employees are included. Firms for which PER changes during the measurement period are not considered. Independent variables are as at the beginning of the measurement period. Model II does not control for LISTING and ACCOUNTING STANDARD because the sample for these estimations includes public firms only for which these two variables both take the value of one. All models are pooled OLS regressions. T-statistics based on Huber/White robust standard errors clustered by firms are presented in parentheses. ***, ** and * indicate significance on the $1 \%-, 5 \%$ and $10 \%$-levels, respectively. A detailed description of all variables can be found in Appendix A.

\begin{tabular}{|c|c|c|c|c|}
\hline \multirow[t]{2}{*}{ Model } & $\begin{array}{l}\text { Ia } \\
\text { accoun }\end{array}$ & $\mathrm{Ib}$ & IIa & ity \\
\hline & $\sigma($ cash flow $)$ & $\sigma(\mathrm{ROA})$ & $\sigma_{\text {idio. }}$ & $\log \left(\sigma_{\text {idio. }}\right)$ \\
\hline PER & $\begin{array}{c}-0.025^{* *} \\
(-2.08)\end{array}$ & $\begin{array}{c}-0.031 * \\
(-1.84)\end{array}$ & $\begin{array}{c}-0.072 * * \\
(-2.15)\end{array}$ & $\begin{array}{l}-0.16^{*} \\
(-1.84)\end{array}$ \\
\hline Leverage & $\begin{array}{c}-0.0099 \\
(-0.69)\end{array}$ & $\begin{array}{l}-0.021 \\
(-1.33)\end{array}$ & $\begin{array}{l}0.081 \\
(0.79)\end{array}$ & $\begin{array}{c}0.019 \\
(0.086)\end{array}$ \\
\hline Size & $\begin{array}{c}0.0068^{*} \\
(1.70)\end{array}$ & $\begin{array}{c}0.010^{*} \\
(1.79)\end{array}$ & $\begin{array}{l}-0.011 \\
(-0.60)\end{array}$ & $\begin{array}{l}-0.039 \\
(-0.98)\end{array}$ \\
\hline Tangibility & $\begin{array}{l}-0.021 \\
(-0.99)\end{array}$ & $\begin{array}{l}-0.016 \\
(-0.66)\end{array}$ & $\begin{array}{l}-0.099 \\
(-1.31)\end{array}$ & $\begin{array}{l}-0.33^{*} \\
(-1.77)\end{array}$ \\
\hline $\mathrm{ROA}$ & $\begin{array}{c}0.21^{* * *} \\
(3.63)\end{array}$ & $\begin{array}{c}0.21^{* * *} \\
(2.77)\end{array}$ & $\begin{array}{c}-0.46 * * * \\
(-4.21)\end{array}$ & $\begin{array}{c}-1.37 * * * \\
(-4.14)\end{array}$ \\
\hline TobQ ${ }_{i n d}$ & $\begin{array}{l}-0.013 \\
(-0.86)\end{array}$ & $\begin{array}{l}-0.025 \\
(-1.22)\end{array}$ & $\begin{array}{l}-0.052 \\
(-1.19)\end{array}$ & $\begin{array}{c}-0.12 \\
(-1.02)\end{array}$ \\
\hline Sales growth & $\begin{array}{c}-0.029^{* *} \\
(-2.18)\end{array}$ & $\begin{array}{l}-0.025 \\
(-1.35)\end{array}$ & $\begin{array}{l}-0.020 \\
(-0.51)\end{array}$ & $\begin{array}{l}-0.012 \\
(-0.11)\end{array}$ \\
\hline Listing & $\begin{array}{c}0.0030 \\
(0.26)\end{array}$ & $\begin{array}{l}0.015 \\
(1.13)\end{array}$ & & \\
\hline Acc. Std. & $\begin{array}{l}-0.010 \\
(-0.78)\end{array}$ & $\begin{array}{l}-0.016 \\
(-1.10)\end{array}$ & & \\
\hline Observations & 153 & 153 & 107 & 107 \\
\hline Firms & 57 & 57 & 30 & 30 \\
\hline Adj. $R^{2}$ & 0.51 & 0.49 & 0.67 & 0.69 \\
\hline Industry FE & yes & yes & yes & yes \\
\hline Year FE & yes & yes & yes & yes \\
\hline Polynomial & four & four & four & four \\
\hline / either side & yes & yes & yes & yes \\
\hline
\end{tabular}




\section{Appendix}

Appendix A Definition of variables

\begin{tabular}{|c|c|}
\hline Variable & Description \\
\hline \multicolumn{2}{|c|}{ Main variables } \\
\hline Leverage & $\begin{array}{l}\text { Total debt divided by total debt plus book value of equity. Total debt } \\
\text { includes current and long-term liabilities and excludes provisions and ac- } \\
\text { cruals. Source: Hoppenstedt (HS). }\end{array}$ \\
\hline PER & $\begin{array}{l}\text { Dummy which equals one if the firm has parity employee representation. } \\
\text { Source: Hand-collected. }\end{array}$ \\
\hline $\mathrm{DE}$ & Number of domestic employees. Source: HS and hand-collected. \\
\hline Treated & $\begin{array}{l}\text { Dummy which equals one for firms which introduced PER during the in- } \\
\text { troduction period of the codetermination law. Source: Hand-collected. }\end{array}$ \\
\hline Post $_{i n t r}$ & $\begin{array}{l}\text { Dummy which equals one after 1979, i.e., after the end of the introduction } \\
\text { period of the law on codetermination. }\end{array}$ \\
\hline \multicolumn{2}{|c|}{ Control variables } \\
\hline Size & Natural logarithm of total assets in Mio $€$. Source: HS. \\
\hline $\mathrm{ROA}$ & $\begin{array}{l}\text { Earnings scaled by total assets. Earnings before interest and taxes are used } \\
\text { for the RD sample. For the law introduction sample, we use net income } \\
\text { due to data constraints. Source: HS. }\end{array}$ \\
\hline Tangibility & Long-term tangible assets scaled by total assets. Source: HS. \\
\hline TobQ ${ }_{i n d}$ & $\begin{array}{l}\text { Median of TobQ in an industry (based on the Fama/French } 38 \text { industries } \\
\text { classification) and year. TobQ is calculated as market value of equity } \\
\text { plus total liabilities divided by the sum of book value of equity and total } \\
\text { liabilities }\left(\frac{w c 08001+w c 03351}{w c 03501+w c 03351}\right) \text {. Source: Own calculation based on WC. }\end{array}$ \\
\hline Listing & $\begin{array}{l}\text { Dummy that equals one if shares of the firm are listed on any EU-regulated } \\
\text { or exchange-regulated market in Germany. Source: Hand-collected. }\end{array}$ \\
\hline Acc. Std. & $\begin{array}{l}\text { Dummy that equals one if a firm applies international accounting stan- } \\
\text { dards. Source: HS. }\end{array}$ \\
\hline \multicolumn{2}{|c|}{ Bank ownership } \\
\hline Bank & $\begin{array}{l}\text { Dummy which equals one if a bank holds voting rights of the company. } \\
\text { Source: own calculations based on HS. }\end{array}$ \\
\hline Post $_{t a x}$ & Dummy which equals one after 2001. \\
\hline $\mathrm{PER}_{\text {pre }}$ & $\begin{array}{l}\text { Parity employee representation as before the tax reform (i.e., measured in } \\
\text { 1999). Source: Hand-collected. }\end{array}$ \\
\hline Free float & Fraction of shares in free float. Source: HS. \\
\hline \multicolumn{2}{|c|}{ Loan variables (source: Dealscan) } \\
\hline Spread & Spread all-in-drawn. \\
\hline Maturity & Natural logarithm of deal maturity in months. \\
\hline Covenants & $\begin{array}{l}\text { Number of covenants for the deal. If no information on covenants is avail- } \\
\text { abe, we set the variable to zero. }\end{array}$ \\
\hline Amount & Natural logarithm of the facility amount. \\
\hline Purpose & Dummy which equals one if primary purpose is "corporate purpose". \\
\hline
\end{tabular}


Definition of variables - continued

\begin{tabular}{|c|c|}
\hline Variable & Description \\
\hline \multicolumn{2}{|c|}{$M E \mathcal{G} A$ deals (source: SDC Platinum) } \\
\hline M\&A deal & Dummy which equals one if a firm conducts an M\&A deal. \\
\hline \# deals & Number of M\&A deals. \\
\hline CAR & $\begin{array}{l}\text { Cumulative abnormal return around the announcement of a M\&A deal. } \\
\text { Normal returns are estimated with a market model; the CDAX is used } \\
\text { as the market index. The estimation period is } 200 \text { trading days ending } \\
\text { two months before the announcement date. Events with fewer than } 150 \\
\text { observations during the estimation period are not considered. The CAR is } \\
\text { measured during a symmetric three or five day window around the event. }\end{array}$ \\
\hline CER & $\begin{array}{l}\text { Cumulative excess return. Excess return is defined as return above the } \\
\text { market index, i.e., the CDAX. }\end{array}$ \\
\hline Diversifying deal & $\begin{array}{l}\text { Dummy which equals one if the firm acquires a target outside its main } \\
\text { business segment (as indicted by the SDC macro industry). }\end{array}$ \\
\hline International deal & Dummy which equals one if the target is located outside Germany. \\
\hline \multicolumn{2}{|l|}{ Stability $\&$ risk } \\
\hline$\sigma($ cash flow $)$ & $\begin{array}{l}\text { Standard deviation of cash flow scaled by total assets over the previous } \\
\text { three fiscal years. Cash flow is defined as sales minus total expenses plus } \\
\text { depreciation. Source: Own calculations based on HS. }\end{array}$ \\
\hline$\sigma(\mathrm{ROA})$ & $\begin{array}{l}\text { Standard deviation of ROA over the previous three fiscal years. Source: } \\
\text { Own calculations based on HS. }\end{array}$ \\
\hline$\sigma_{i d i o}$ & $\begin{array}{l}\text { Yearly measure for idiosyncratic risk (Panousi and Papanikolaou, 2012). } \\
\text { Calculated as volatility of weekly residuals. Residuals are obtained from a } \\
\text { regression of firm's equity returns on the market return (CDAX). } \sigma_{i d i o} \text { for } \\
\text { firm i in year t is then calculated as } \sigma_{i d i o}^{i, t}=\sqrt{\sum \epsilon_{i, \tau}^{2}} \text {; with } \epsilon_{i, \tau} \text { being the } \\
\text { residual from the first regression in week } \tau \text {. Equity returns are calculated } \\
\text { based changes of the Datastream item RI (return index) between week t- } 1 \\
\text { and t. Some adjustments are made for equity returns (i.e., deletion of all } \\
\text { observations with unadjusted price below one and observations where the } \\
\text { same price is reported for at least three consecutive weeks). Source: Own } \\
\text { calculations based on DS. }\end{array}$ \\
\hline \multicolumn{2}{|l|}{ Other variables } \\
\hline Sales Growth & Sales growth between year t and year t-1. Source: HS. \\
\hline Z-Score class & $\begin{array}{l}\text { Z-Score is calculated as } 0.717^{*} \times 1+0.847^{*} \times 2+3.107^{*} \times 3+0.420^{*} \times 4+ \\
0.998^{*} \times 5 \text { with } \times 1=\frac{\text { short-term assets-short-term liabilities }}{\text { total assets }} \times \text { x } 2=\frac{\text { setained earnings }}{\text { total assets }} ; \\
\mathrm{x} 3=\frac{\text { EBIT }}{\text { total assets }} ; \mathrm{x} 4=\frac{\text { total equity }}{\text { total liabilities }} ; \mathrm{x} 5=\frac{\text { sales }}{\text { total assets }} \text {. Z-Score class equals } \\
\text { minus one if Z-Score is above } 2.9 \text {, one if below } 1.22 \text {, and zero if between } \\
1.22 \text { and } 2.9 \text {. Source: Own calculations based on HS. }\end{array}$ \\
\hline
\end{tabular}

$H S$ stands for Hoppenstedt, DS for Dealscan, and WC for Worldscope. 